DOE/ID-10551

\title{
Mixed Waste Focus Area Program Management Plan
}

\author{
Dr. George A. Beitel
}

Published October 1996

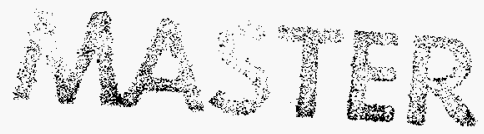

\section{Idaho National Engineering Laboratory Lockheed Martin Idaho Technologies Company Idaho Falls, Idaho $\mathbf{8 3 4 1 5}$}

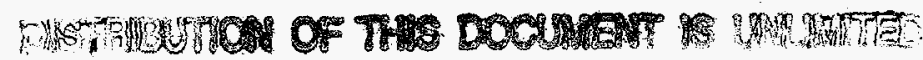

Prepared for the U.S. Department of Energy

Environmental Management Mixed Waste Focus Area Program Under DOE Idaho Operations Office Contract DE-AC07-941D13223 


\section{DISCLAIMER}

This report was prepared as an account of work sponsored by an agency of the United States Government. Neither the United States Government nor any agency thereof, nor any of their employees, makes any warranty, express or implied, or assumes any legal liability or responsibility for the accuracy, completeness, or usefulness of any information, apparatus, product, or process disclosed, or represents that its use would not infringe privately owned rights. Reference herein to any specific commercial product, process, or service by trade name, trademark, manufacturer, or otherwise does not necessarily constitute or imply its endorsement, recommendation, or favoring by the United States Government or any agency thereof. The views and opinions of authors expressed herein do not necessarily state or reflect those of the United States Government or any agency thereof. 


\section{DISCLAMMER}

Portions of this document may be illegible in electronic image products. Images are produced from the best available original document. 


\section{CONTENTS}

ACRONYMS

vii

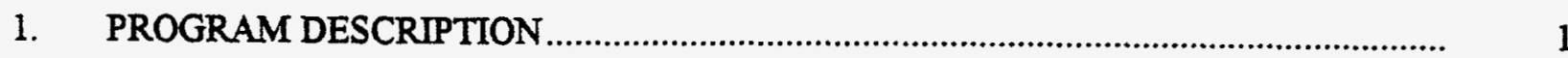

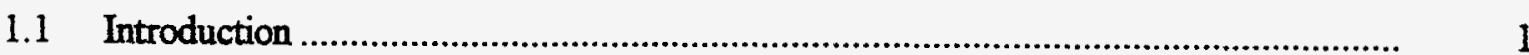

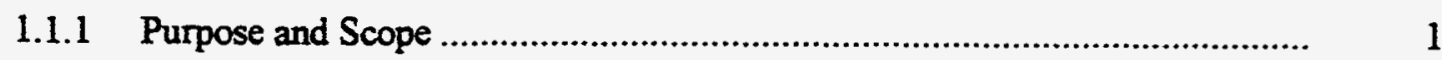

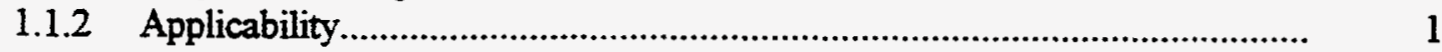

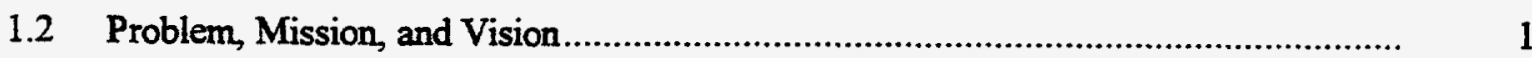

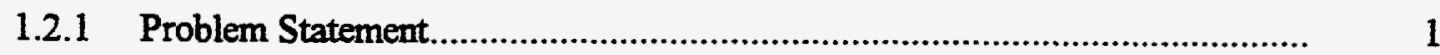

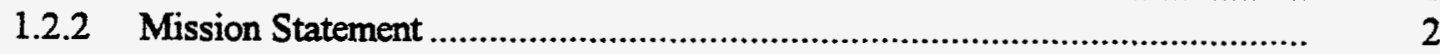

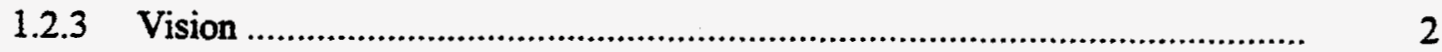

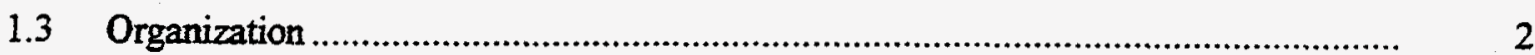

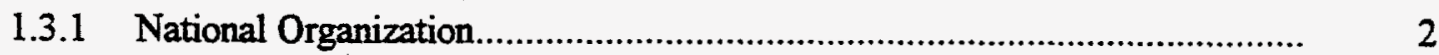

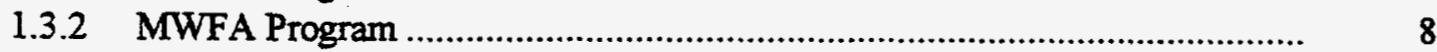

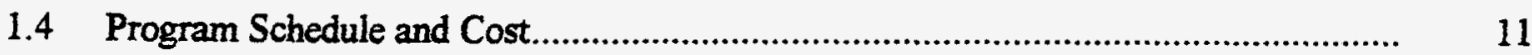

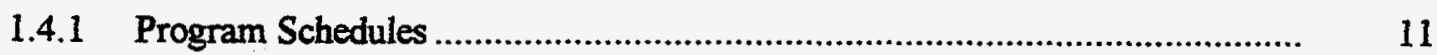

1.4.2 Program Cost .............................................................................. 11

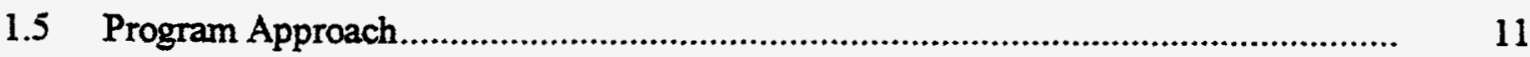

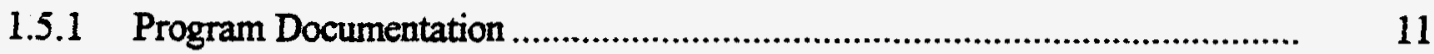

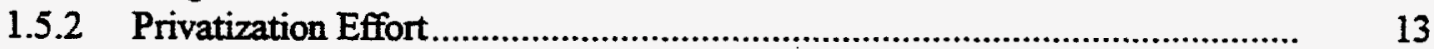

1.5.3 University Support ............................................................................... 13

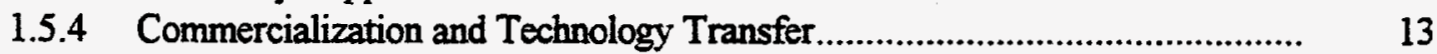

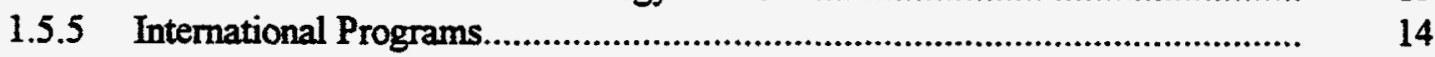

1.5.6 Basic Research ................................................................................ 14

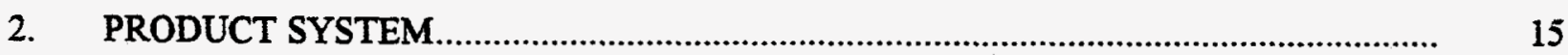

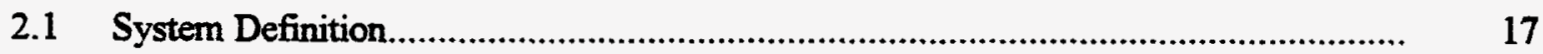

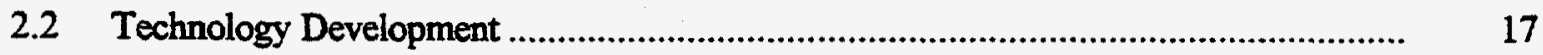

2.2.1 Neds Identification and Analysis........................................................ 17

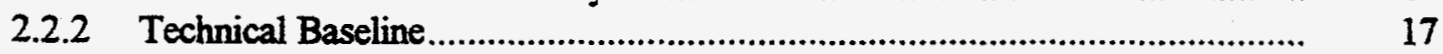

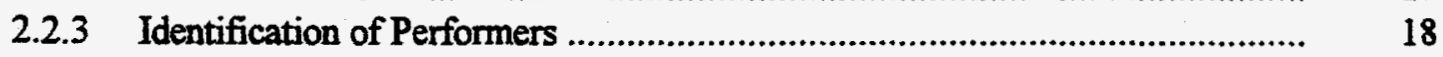

2.2.4 Integrated Master Schedule ............................................................... 18

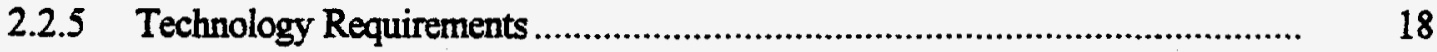

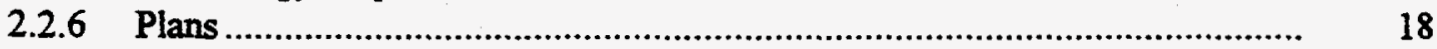

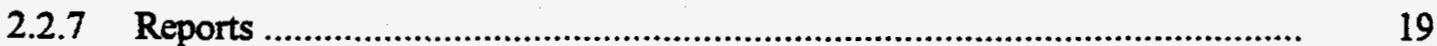


2.3 Quality Assurance.

2.3.1 Documentation ................................................................................ 20

2.3.2 Requirements Management and Control .................................................. 20

2.3.3 Data Quality Objectives....................................................................... 20

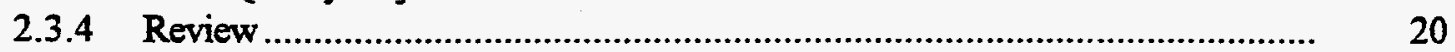

2.3.5 Trade Studies and Systems Analyses...................................................... 20

2.4 The Product-Technology Performance Reports.................................................. 20

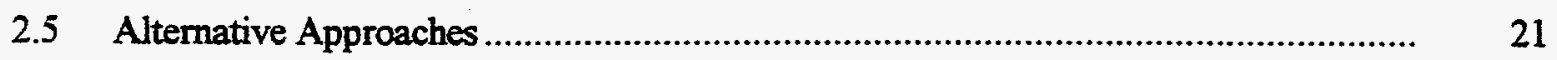

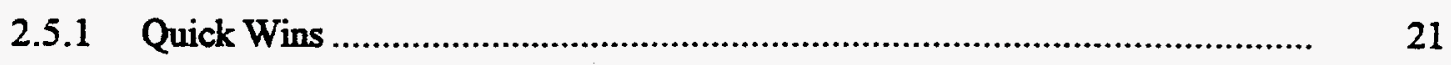

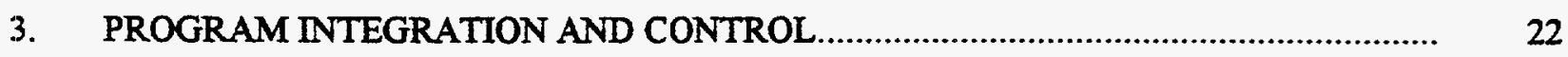

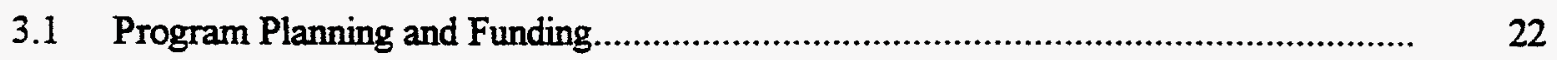

3.1.1 Budget Formulation ................................................................... 22

3.1.2 Work Breakdown Structure ................................................................... 22

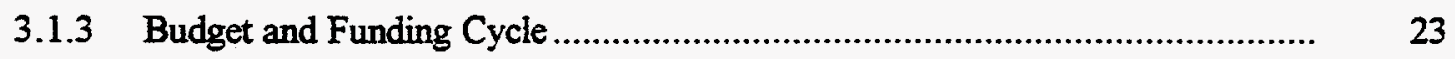

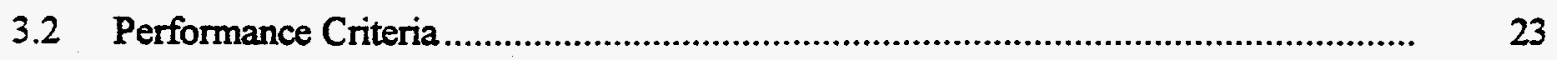

3.2.1 Technical Performance Criteria .............................................................. 23

3.2.2 Cost Performance Criteria ...................................................................... 23

3.2.3 Schedule Performance Criteria..................................................................... 23

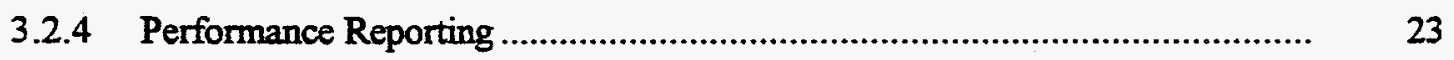

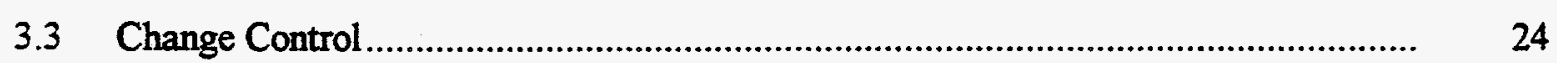

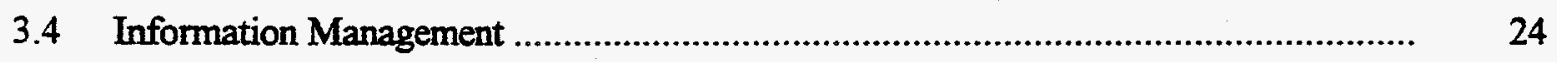

3.4.1 Internet Information Availability ....................................................... 25

3.4.2 Document Configuration Control ........................................................ 25

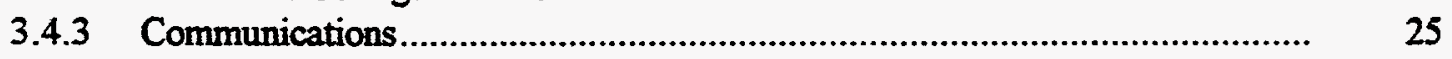

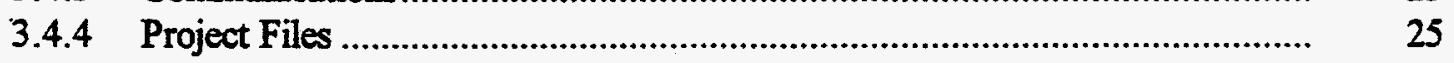

3.5 Quality Assurance, Environmental Health and Safety, and Security......................... 25

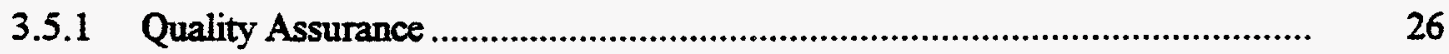

3.5.2 Safety and Health Plan .................................................................... 26

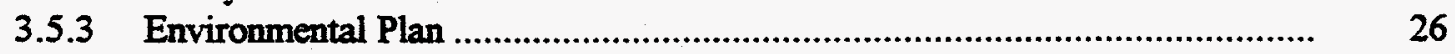

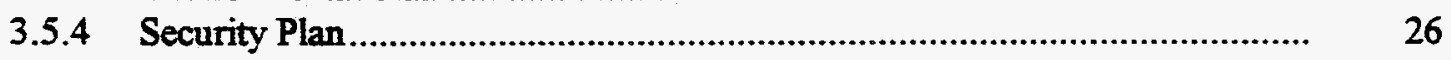

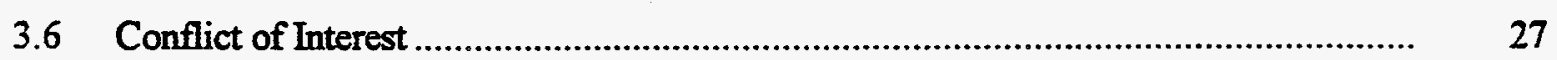

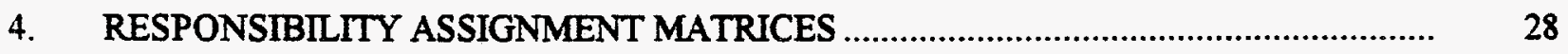




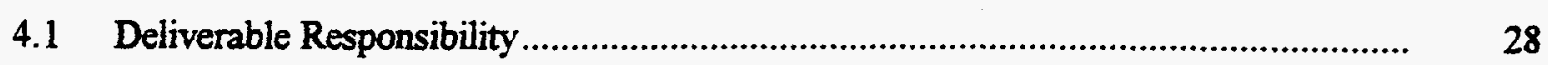

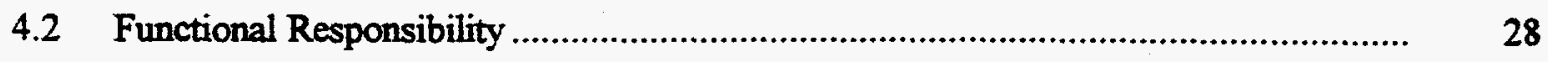

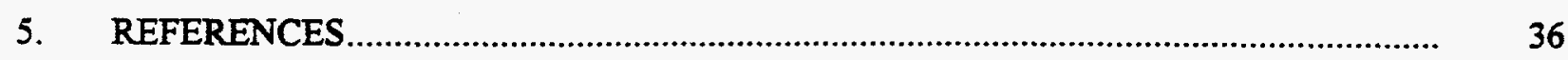

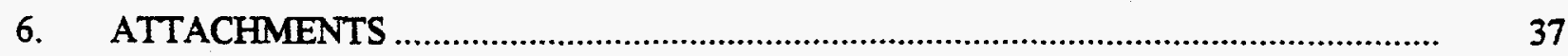

\section{FIGURES}

1. Mixed Waste Focus Area National Organization. .................................................. 3

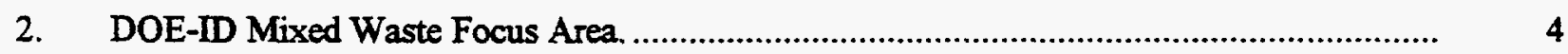

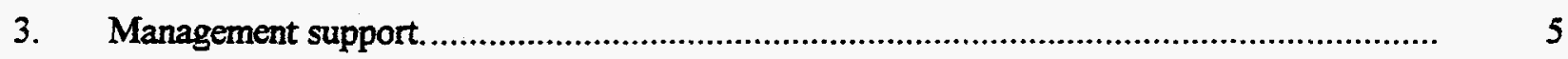

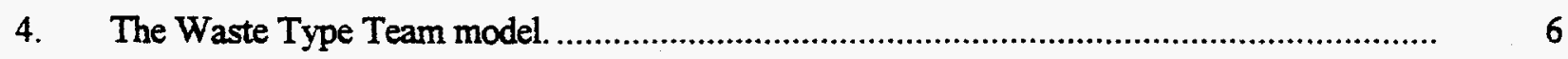

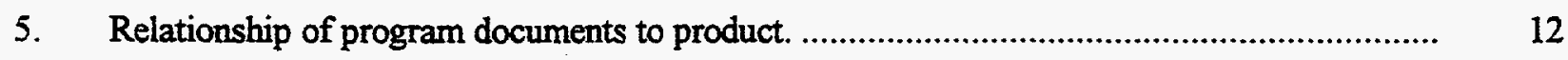

6. Mixed Waste Focus Area based on Systems Engineering Process................................ 16

\section{TABLES}

1. MWFA document responsibility and assignment matrix ........................................... 28

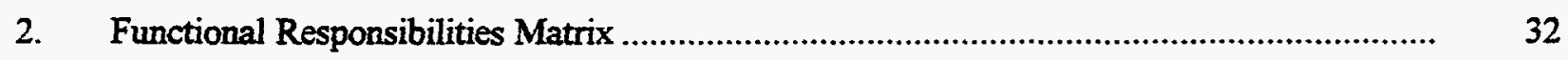




\section{ACRONYMS}

ADS

Activity Data Sheet

BCWP

Budgeted Cost of Work Performed

BCWS Budgeted Cost of Work Scheduled

CBD Commerce Business Daily

CMST Characterization, Monitoring, and Sensor Technology

DOE

U.S. Department of Energy

DOE-ID Department of Energy-Idaho Operations Office

DP Development Plan

EM Environmental Management (Office of Environmental Restoration and Waste Management, Department of Energy)

EPA Environmental Protection Agency

ES\&H Environmental, Safety, and Health

ESP Efficient Separation Program

FinPlan Financial Plan

FTP File Transfer Protocol

IPS Integrated Program Schedule

IMS Integrated Master Schedule

INEL Idaho National Engineering Laboratory

ITRC Interstate Technology Regulatory Cooperation Work Group

LMITCO Lockheed Martin Idaho Technologies Company

LLW Low-Level Waste

MWFA Mixed Waste Focus Area

NTW National Technical Work Group

OCI Organizational Conflicts of Interest 


\begin{tabular}{ll} 
OMB & Office of Management and Budget \\
PEG & Program Execution Guidance \\
PI & Principal Investigator \\
PMP & Program Management Plan \\
PTS & Progress Tracking System \\
QAP & Quality Assurance Program \\
RFI & Request-For-Expressions-of-Interest \\
STCG & Site Technology Coordination Group \\
TDRD & Technology Development Requirements Document \\
TPO & Technical Program Officer \\
TPR & Technology Performance Report \\
TIP & Technical Task Plan \\
WBS & Work Breakdown Structure \\
WTM & Waste Type Manager \\
WTT & Waste Type Team \\
\hline
\end{tabular}




\section{Mixed Waste Focus Area Program Management Plan}

\section{PROGRAM DESCRIPTION}

\subsection{Introduction}

This Program Management Plan (PMP) was prepared for the Mixed Waste Focus Area (MWFA) Program. The MWFA program is managed by the Department of Energy Idaho Operations Office (DOE-ID) and supported by the Lockheed Martin Idaho Technologies Company (LMTCO). The program funding is received under ADS Number HQ-0000-MW-00. The LMTTCO support is managed under DOE-ID Contract DE-AC07-94ID13223.

This PMP is based on the "Idaho National Engineering Laboratory (INEL) Proposal, Lead Organization for the Mixed Waste Focus Area", dated December 1, 1994. Implementing and technical documents will be prepared as discussed within this plan.

\subsubsection{Purpose and Scope}

This plan describes the program management principles and functions to be implemented in the MWFA. It includes all of the topics recommended by Department of Energy (DOE) Order 4700.1 to be addressed in a PMP. The emphasis on systems engineering paralleling DOE 0 430.1, Life-Cycle Asset Management, offers a noticeable departure from prior PMPs written to DOE ORDER 4700.1.

\subsubsection{Applicability}

The policy and directives of this PMP are applicable to the U.S. Department of Energy-Idaho Operations Office Mixed Waste Focus Area, the LMITCO MWFA Program Office, and to all contractors and Federal agencies supporting the MWFA.

Implementing procedures will be written to cover MWFA management practices at the INEL. MWFA contractors and participants not located at the INEL shall prepare their own implementing procedures by reference and modification of their own corporate procedures such that there is consistency between the resulting procedures and this document.

\subsection{Problem, Mission, and Vision}

DOE EM-50 is the sponsor of the MWFA. The Operations Offices, EM-30, EM-40, and EM-60, are the primary end-users of treatment systems and treatment technologies, and are therefore customers for MWFA products.

\subsubsection{Problem Statement}

The problem the MWFA program addresses is quoted from the January 25, 1994, Action Plan, "A New Approach to Environmental Research and Technology Development at the U.S. Department of Energy." 
"Several conflicting regulations and lack of definitive mixed waste treatment standards hamper mixed waste activities. Disposal capacity for mixed waste is also expensive and severely limited. DOE now spends millions of dollars annually to store mixed waste because of lack of accepted treatment technology and disposal capacity. Currently available waste management practices require extensive, and hence expensive, waste characterization before disposal. Therefore, DOE must pursue technology that leacls to better and less expensive characterization, retrieval, handling, treatment and disposal of mixed waste."

\subsubsection{Mission Statement}

The mission of the MWFA is to provide acceptable technologies that enable implementation of mixed waste treatment systems developed in partnership with end-users, stakeholders, tribal governments, and regulators.

The MWFA will develop, demonstrate and deliver implementable technologies for treatment of mixed waste within the DOE Complex. Treatment refers to all post waste-generation activities including sampling and analysis, characterization, storage, processing, packaging, transportation and disposal.

\subsubsection{Vision}

The MWFA will implement a program that is so well managed, integrated, and technically defensible that public and tribal representatives, regulators, and end-users will advocate its approach and implement the resulting technologies.

\subsection{Organization}

The organization is presented in two sections, (1) the National Organization, shown in Figure 1, which portrays an overview of the MWFA ties to DOE, the principal tribes and stakeholders, and the principal investigators, and, (2) the MWFA Program, which includes organizations with a funding, contractual, or agreement vehicle that establishes a reporting tie to DOE-ID. The MWFA program consists of the DOE-ID MWFA organization, Figure 2, LMITCO program management support group, Figure 3, and the Waste Type Team, Figure 4.

\subsubsection{National Organization}

The DOE Office of Environmental Management, Office of Science and Technology Development, EM-50, sponsors the MWFA. The EM-50 Deputy Assistant Secretary retains the sole and final authority to determine the direction, execution, and funding of the MWFA by EM-50. DOE coordinates MWFA activities with national stakeholder organizations, other federal agencies, and international organizations and governments.

1.3.1.1 EM-50. EM-50 sets program policy and direction and approves focus area budgets and funding. For projects which are jointly funded by EM-50 and another DOE office, or other agency, a formal agreement will be prepared to delineate individual responsibilities and commitments. The MWFA is supported by three offices within EM-50; Office of Science and Risk Policy (EM-52), Office of Technology Systems (EM-53), and the Office of Technology Integration (EM-54). EM-53 focus area program managers are assigned to provide the first point of contact between the MWFA Program Office 


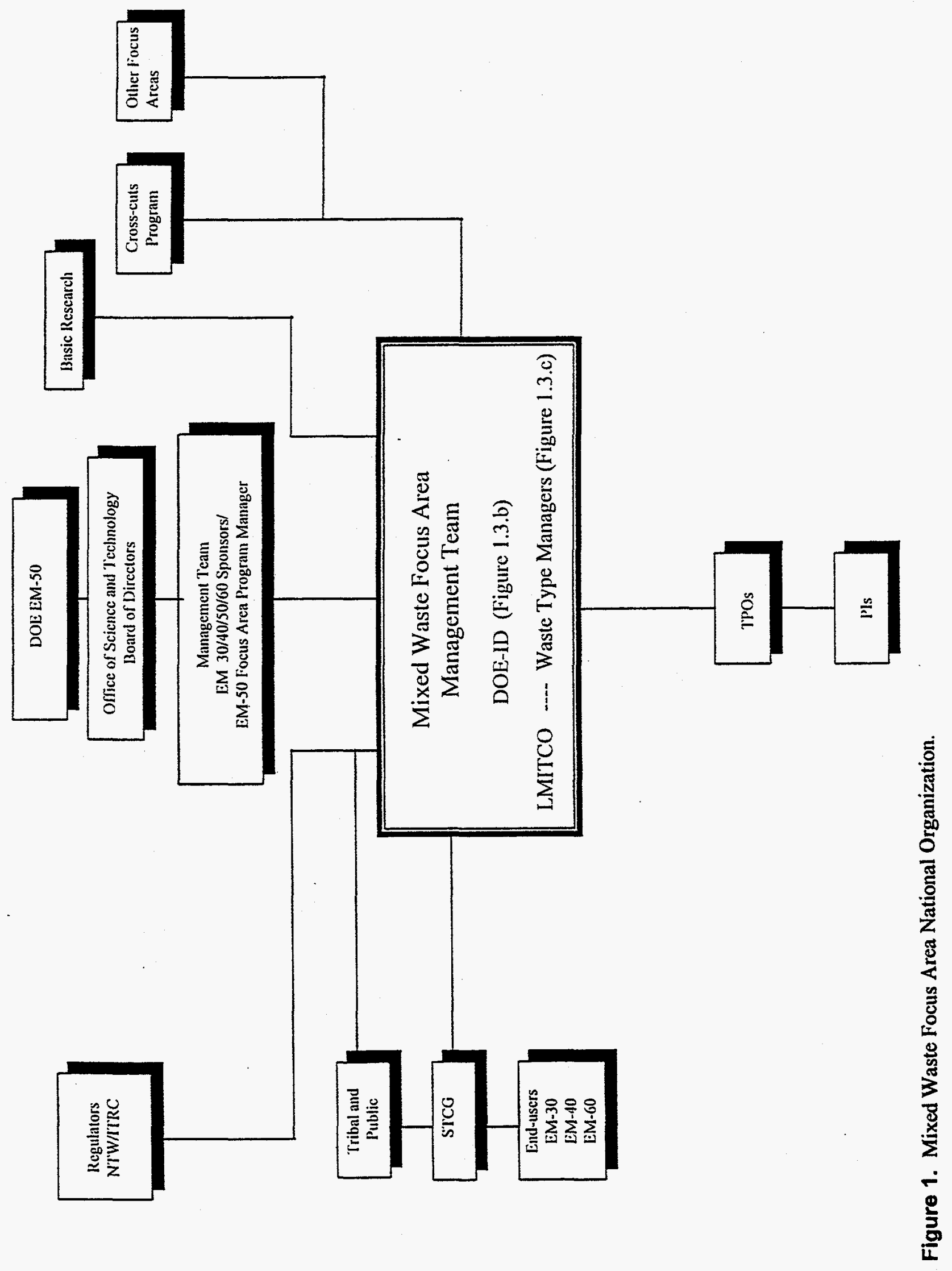




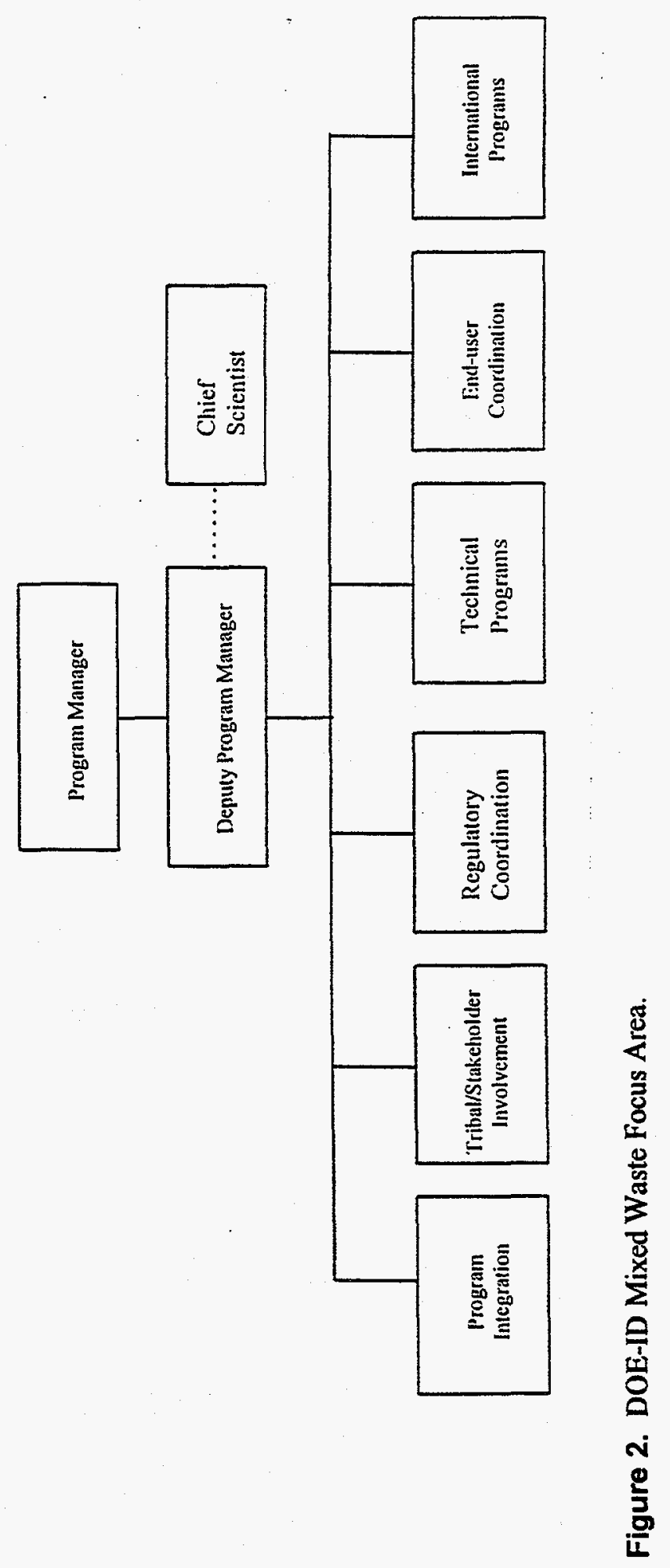




\section{Management Support}

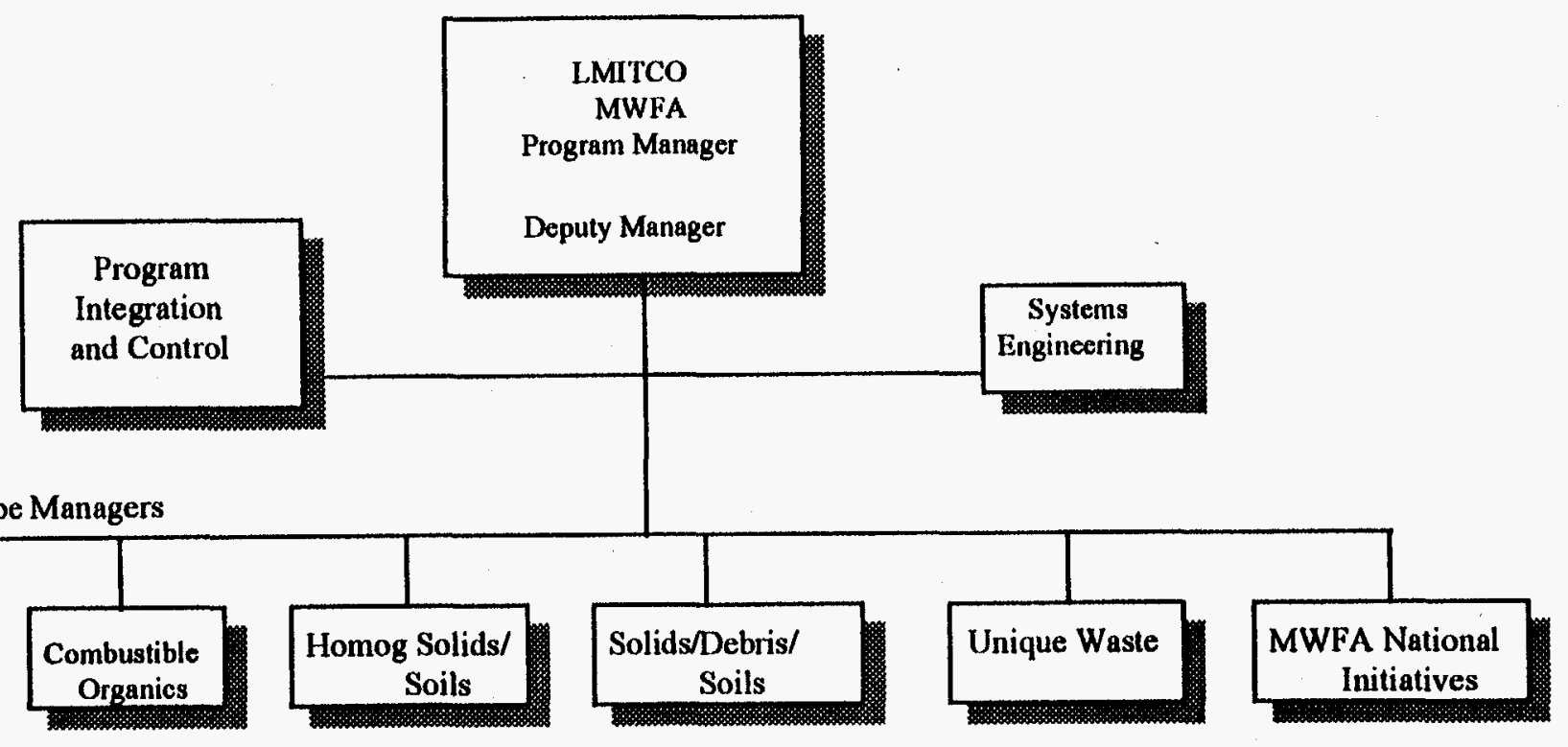

Waste Type Team Support

Contacts
Waste Type Team Points-of-Contact
Site Operations Contacts

Figure 3. Management Support. 


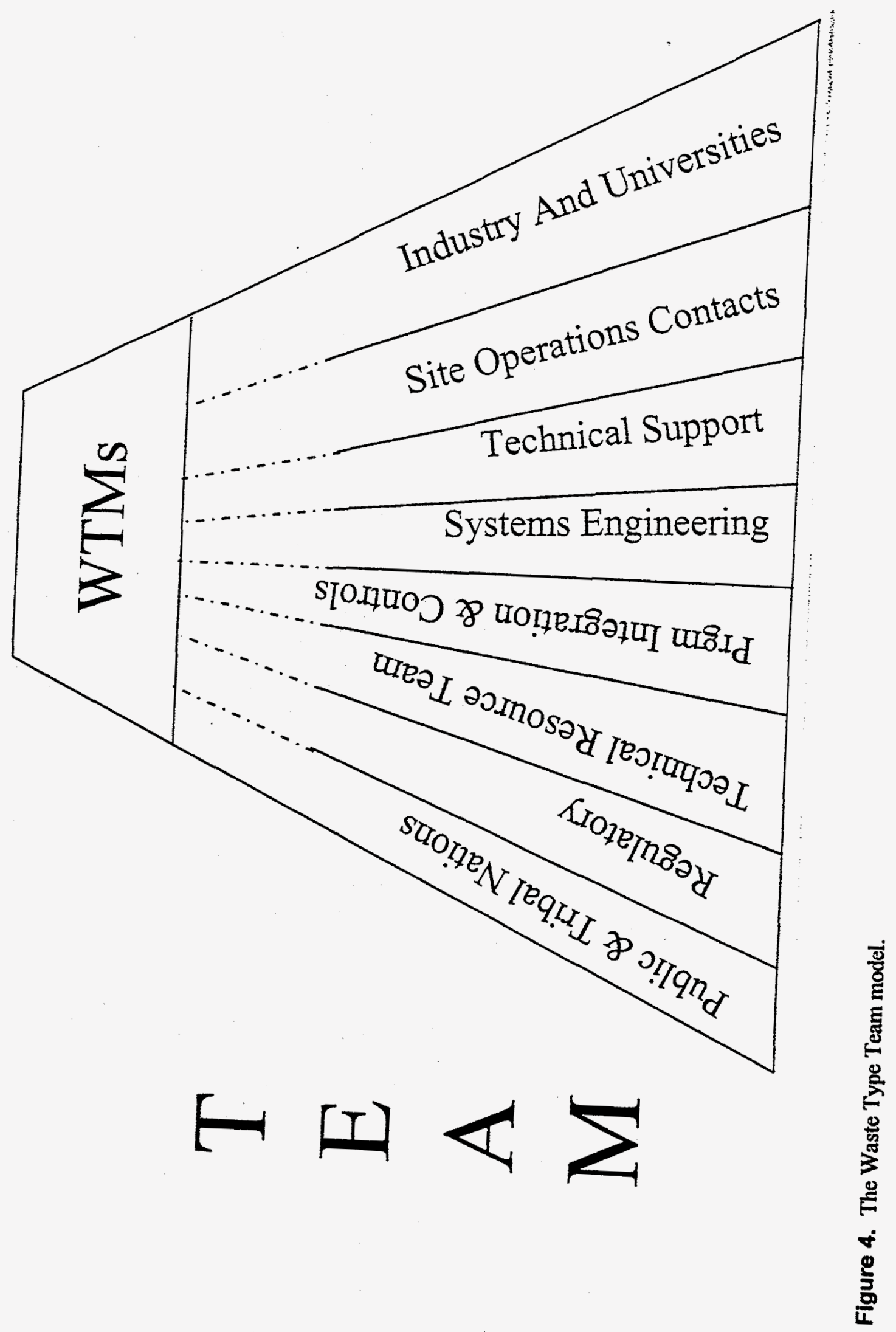


and EM-50. Other EM-50 staff are assigned to provide interfaces between the MWFA, other focus areas, and cross-cut programs and represent other DOE interests, as required.

\subsubsection{Office of Science and Technology Board of Directors. The Office of Science and} Technology Board of Directors is composed of the Deputy Assistant Secretaries of EM-30, -40 and -50, and the Operations Office Managers from the sites at which focus areas and Industry Programs are located (Idaho, Morgantown, Richland, and Savannah River). This committee provides strategic direction and oversight and ensures that the technology development program continues to be responsive to EM priorities. The committee reviews actions of each Management or Implementation Group; establishes overall priorities; provides strategic and programmatic direction and issues resolution for the focus areas; and addresses procedural and coordination issues that cross-cut focus areas.

1.3.1.3 Management Team. The DOE MWFA Management Team is composed of representatives from EM-30, $-40,-50$, and -60 , and the EM-50 focus area program manager. This team maintains cognizance of the status of the MWFA technology development efforts. The team advises the MWFA of global policies, programmatic needs and policies, and interface issues. By interfacing directly with the environmental operations offices, this team facilitates liaison between EM-30, 40, and 60 end-users and the MWFA.

1.3.1.4 End-Users-EM-30, -40, and-60. EM-30, -40, and -60 are responsible for all low-level, high-level, and transuranic waste operations, as well as site remediation and facility decontamination and decommissioning. EM-50 is chartered to provide technology to EM-30, -40 , and -60 to improve their operational capability. Therefore, EM-30, -40 , and -60 are the primary customers of the MWFA and the end-users of any technology developed.

1.3.1.5 Peer Review. Peer review of focus area technical products and activities is provided on an asrequired basis. Groups such as the National Academy of Sciences can be invited to participate. The American Society of Mechanical Engineers may provide peer review of specific MWFA products. The Assistant Secretary, Environmental Management or the Deputy Assistant Secretary, EM-50, may solicit peer review for advice on high-level priority and resource issues and overall programmatic matters.

1.3.1.6 Technical Program Officer. Each DOE Operations Office conducting work funded through the MWFA will designate a Technical Program Officer (TPO) to support planning and implementation of development activities, relative to that Operations Office, conducted under Technical Task Plans funded by the MWFA program. The TPOs are responsible for day-to-day implementation of these activities, including scope, cost, schedule, and reporting to the MWFA. The TPOs encourage and maintain open and ongoing communications with the DOE-ID MWFA Program Manager, EM-30, -40, and -60 program managers, Site Technology Coordination Groups, other DOE Operations Offices, other programs, and local stakeholders, tribal governments, and regulators.

1.3.1.7 Principal Investigators. A Principal Investigator (PI) is a senior member of a development or demonstration group of a task being funded through the MWFA. Principal Investigators are responsible for the performance, technical progress, and direction of technology development and demonstration activities.

1.3.1.8 Other Focus Areas and Cross-cut Programs. EM-50 supports four focus areas: Subsurface Contaminants, Tanks (high-level waste), Decontamination and Decommissioning, and Mixed Waste. Communication and interfaces are actively maintained between these focus areas to avoid duplication of efforts. Communication channels begin at EM-50 and extend to the lowest level necessary. 
In addition to focus areas, EM-50 has Industry Programs and four cross-cut programs (programs which address technologies of applicability to more than one focus area): Characterization, Monitoring and Sensor Technology (CMST), Efficient Separations and Processing, and Robotics. As with the focus areas, communication and interfaces are actively maintained between these programs to avoid duplication of efforts. Where practicable, these programs will provide the technology research and development as requested by the focus areas.

\subsubsection{Other Interfacing Organizations}

1.3.1.9.1 Site Technology Coordination Groups-Each primary DOE site within the DOE Complex has a Site Technology Coordination Group (STCG). The STCGs consolidate and prioritize their site technology needs. These site specific needs are conveyed to the focus areas for integrated planning, funding and execution of technology development. The STCG provides the primary communication between the site they represent, the MWFA, and local tribes, stakeholders, and regulators on technology development, life-cycle planning, and technology transfer.

1.3.1.9.2 National Technical Work Group-The National Technical Work Group (NTW) was formed by EM-30 and the Environmental Protection Agency (EPA) Office of Solid Waste. The purpose of the NTW is to assist the Environmental Protection Agency (EPA), DOE, and States in the development and implementation of various tasks needed for permitting mixed waste treatment facilities. The mission of the NTW is to support the development of coordinated, consistent, and environmentally protective national permit procedures for mixed waste treatment. The MWFA participates with the NTW to facilitate continued acceptance and permitting of new technologies and innovative utilization of those technologies. Products produced by the NTW have facilitated new innovative strategies in the characterization of wastes and trial burn plans for thermal technologies.

1.3.1.9.3 Interstate Technology Regulatory Cooperation Work Group-The Interstate Technology and Regulatory Cooperation Work Group (ITRC) was created by representatives of state regulators and chartered under the Western Governors Association to provide multi-state participation in acceptance of demonstration testing protocols. To date six states operate under a memo-of-understanding that allows these states to accept each other's test results. This enables technology demonstrations to occur in one state and the results to be accepted in other states, thus eliminating the cost of multi-state demonstrations. The ITRC has been a valuable resource in making contacts with States and Department of Defense technology development efforts.

1.3.1.9.4 Basic Research-There are many organizations external to the MWFA from which the MWFA may seek assistance relative to basic research. There are many organizations external to the MWFA from which the MWFA may seek assistance relative to basic research. DOE supports much of this research through the National Laboratories and within universities. Research is also conducted under non-DOE funding. Any of this may be used as input into the MWFA in defining technology requirements and deficiencies.

\subsubsection{MWFA Program}

The MWFA program as described in this section, includes those organizations that contribute to and participate in the MWFA, and are funded in part or in whole by the program. The description in this section is organized principally by programmatic and functional responsibility and not by line organizations. 
1.3.2.1 MWFA Program Management DOE-ID has overall programmatic responsibility and accountability. DOE directs LMITCO and delegates to LMITCO the day-day technical management responsibility and accountability necessary for implementation of projects. LMITCO supports implementation of MWFA strategies through planning, analysis, and systems engineering activities. DOE-ID has approval authority for work proposed by LMITCO.

The DOE-ID MWFA Program Office is headed by a program manager. The MWFA Program Manager provides program policy and strategy, guides the integrated technical approach, and provides toplevel management of the national program. The MWFA Program Manager also recommends program participation and budget targets to EM-50 and end-user programs and interfaces with EM sponsors and end-users throughout the development process.

The DOE-ID program office organization, shown in Figure 2, is structured to facilitate overseeing the various program elements and initiatives. The program manager is assisted by a Deputy Program Manager and a Chief Scientist. Program staff fill the following positions: Program Integration, Tribal/Stakeholder Involvement, Regulatory Coordination, Technical Programs, End-user Coordination, and International Programs.

1.3.2.1.1 LMITCO Management Support-The LMITCO management support organization is shown in Figure 3 and discussed in the following paragraphs. LMITCO management support is headed by a program manager and deputy program manager.

1.3.2.1.2 Program Integration and Contro/-Program Integration and Control provides integration of MWFA program elements, management planning, budget cycle management, central integration of cost and schedule control, periodic reporting to DOE, document control and quality assurance. The details of the Program Integration and Control functions are the principal content of Section 3 of this PMP.

1.3.2.1.3 Systems Engineering-The MWFA is a systems engineered program. Systems engineering principles provide a set of structured processes which transiate problems and/or needs into requirements, and produce a product which meets those requirements. This systems approach is described in greater detail in Section 2 of this PMP.

1.3.2.1.4 Waste Type Managers-The MWFA has categorized all mixed waste streams into five waste types based on the treatability groups defined in the DOE Waste Treatability Guidance, DOE/LLW-217. The five MWFA waste types are (a) waste water slurries, (b) combustible organics, (c) homogeneous solids and soils, (d) debris, solids and soils, and (e) unique wastes. A Waste Type Manager (WTM) is assigned to each of the five waste types. A sixth WTM, National Initiatives, is assigned to address activities that support several of the five primary waste types, e.g., cross-cut activities.

The WTMs were selected through a DOE Complex-wide, open nomination process and have strong backgrounds in EM-30 or EM-40 operations. The Waste Type Managers formally remain in the EM organization at their site.

This increases the tie between technology development and the end-user. WTMs report to LMTTCO, who retains overall responsibility for integration of WTM recommendations. 
1.3.2.2 Waste Type Team. The MWFA program includes one Waste Type Team with shared leadership. The team provides primary decision-making support to DOE. DOE has final responsibility. There are multiple support groups from which the team can draw talent and capability as required.

The Waste Type Team (WTT) is composed of the WTMs and support personnel as required. The WTT will have a mix of skills required to achieve the team objectives. This may include technical and regulatory support, tribal and stakeholder interface personnel, and the customer site operations contact. This is depicted in the Waste Type Team Model in Figure 4.

All technical tasks on the MWFA are carried out within the WTT structure. Furthermore, for the purposes of the MWFA, as will be shown in Section 2 of this PMP, all direct activities related to producing the MWFA product are considered "technical."

A detailed description of roles and responsibilities of the Waste Type Manager and Waste Type Team is published in the Waste Type Team Manual, INEL 95/0522, Attachment D. Specific resources permanently assigned to the MWFA are described in the following paragraphs.

1.3.2.2.1 Waste Type Team Points-of-Contact-Six of the seven WTMs (including a deputy WTM) are located a great distance from the Program Office in Idaho. To facilitate communication between the Program Office and the WTMs, each waste type manager is assigned a point-of-contact whose primary office is in Idaho Falls. The points-of-contact are also members of the Technical Support Group and are available to provide other technical support to the WTT.

13.2.2.2 Site Operations Contact-Each DOE site has designated a cognizant person (from an end-user organization) who provides the single point-of-contact for requesting technical information or status relative to MWFA interests. They are selected for their knowledge of the waste streams and waste treatment facilities at their sites. The WTT Site Operations Contacts provides the key communication link between the MWFA and their site. They are requested to participate in STCG activities at their sites and coordinate needs, priorities, and concerns with the MWFA through the WTMs.

1.3.2.2.3 Resource Groups-There are five resource groups composed of professional, scientific and engineering staff with a mix of skills including waste technology, mechanical and chemical engineering, regulatory, legal, and public affairs.

The groups are:

- Industry and University

- Regulatory

- Technical Support

- Technical Resource Group

- Public and Tribal Nations. 


\subsection{Program Schedule and Cost}

\subsubsection{Program Schedules}

The MWFA operates to two major schedules, the Integrated Program Schedule (IPS) and the Integrated Master Schedule (IMS). The IPS is driven principally to support the budget formulation process, is updated frequently and controlled by Program Integration and Control. The IMS is driven by technology needs related to Site Treatment Plans and Consent Order commitments negotiated in response to the Federal Facility Compliance Act.

\subsubsection{Program Cost}

Program cost is guided by the DOE budget formulation process. The budget formulation process and guidance have been developed by the Office of Financial Management in close consultation with Field and DOE headquarters program management and with input from EM stakeholders. Budget drivers (stakeholder concerns, regulatory requirements, Congressional appropriations, etc.) are identified and considered in the formulation of the project baseline for each technology deficiency.

\subsection{Program Approach}

The MWFA is a requirements driven program based on systems engineered processes (to be described in Section 2) designed to meet the sponsor's (EM-50) and customers' (EM-30, -40, and -60) needs. The requirements flow from the Site Treatment Plans that were prepared in response to the Federal Facility Compliance Act. Product schedules are tied to Consent Order schedules.

Program management and technical management will remain within the DOE and DOE contractor system because the technical problems to be addressed and solved are DOE mixed waste problems.

Technical management will be achieved through the Waste Type Manager concept with the WTMs located within the EM organizations that own the waste problems. This approach has specifically been chosen to maximize the tie between technology development and end-users.

Past experience with technology development programs has shown that lack of public acceptance and failure to incorporate appropriate regulatory requirements has been more of a deterrent to the use of the technology than technological considerations. To overcome this problem, the MWFA has integrated public and tribal involvement and regulatory concerns into the entire development process.

Although much of the development and demonstration may be conducted by DOE contractors, the MWFA seeks the best supplier, independent of organizational identity and relationships. The program is committed to seek support from the private sector, universities and industry as described in Paragraphs 1.5.2 through 1.5.4.

\subsubsection{Program Documentation}

The principal program documents, and their relationship to the program product, are shown in Figure 5. The system documents are described in relationship to the product system that is described in Section 2. Additional documents related to program management, integration, and control are identified in Section 3. The responsibilities for preparing and for approving these documents will be found in Section 4 


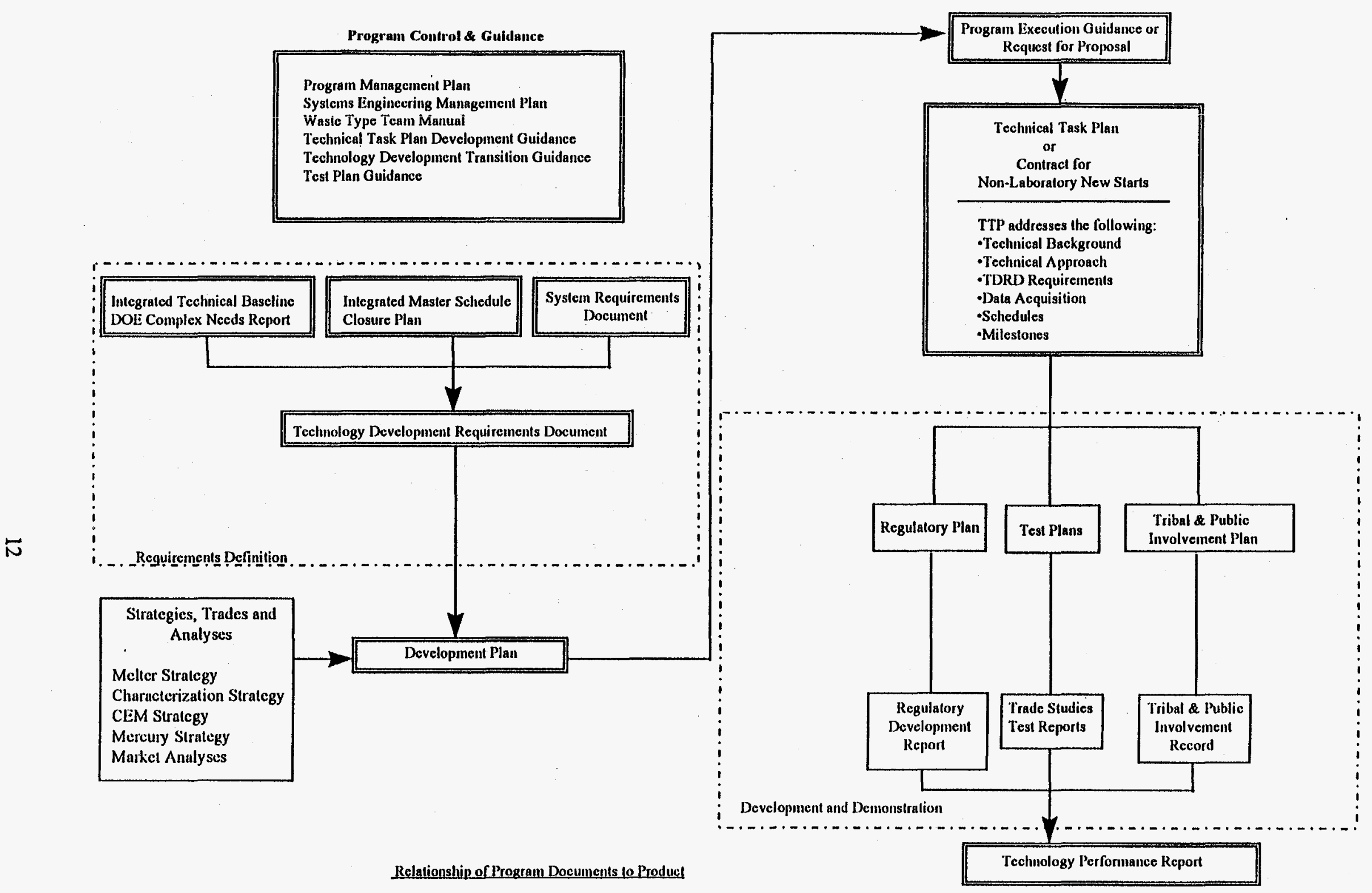

Figure 5. Mixed Waste Focus Area based on Systems Engineering Process. 
of this PMP. This list is not intended to be all inclusive; additional documents will be identified and prepared as the program evolves.

The LMITCO MWFA staff has primary responsibility for preparation of the documents shown in the upper-left quadrant of the figure. These documents control the program processes and provide program-specific guidance for product system activities. These include this PMP, and many of the attachments to this PMP.

The remainder of the figure addresses product system documents, beginning, in the lower-left quadrant, with the requirements definition documents. These documents are prepared by the LMITCO MWFA staff working with the WTMs and WTT.

After requirements have been developed based on customer's needs and a life-cycle plan for developing the technologies has been prepared, the proposal-solicitation and the budget process are activated by the DOE "Program Execution Guidance." This initiates the funding of technology development and demonstration activities.

Technology development and demonstration activities, indicated as "projects," result in products, i.e., implementable technology, that will be documented in Technology Performance Reports. Development and demonstration activities are conducted by PIs and progress under the technical direction of WTMs with the support of the WTT.

\subsubsection{Privatization Effort}

DOE has an initiative, independent of the MWFA, to seek private sector implementation of their waste treatment operations wherever that approach is cost effective. The MWFA will structure its technology development activities to be supportive of the EM privatization efforts. The MWFA plan to support privatization is documented in the Privatization Plan (Attachment $\mathrm{H}$.)

\subsubsection{University Support}

Universities provide the MWFA with several important contributions. First, they provide a source of innovative ideas and solutions to the MWFA technology deficiencies. Second, they provide an existing and efficient research and development partner supporting solutions to MWFA needs. Third, universities can develop and retain expertise that may solve future DOE environmental needs.

The MWFA will identify universities with areas of expertise applicable to MWFA needs. The MWFA will work with these universities to help them understand the MWFA deficiencies so that they can provide solutions to the MWFA. In addition, the MWFA will identify those areas where universities are presently pursuing research in support of other federal agencies. The focus area will work to influence this research in support of the focus area needs.

\subsubsection{Commercialization and Technology Transfer}

Through the MWFA, the government is investing considerable resources in solving the problems associated with the treatment and disposal of mixed waste. The focus area has an obligation to maximize this investment. Policies and procedures will be developed by the focus area to maximize the potential to commercialize technologies supported by the focus area. These efforts will support direct 
commercialization by the private sector and the sale of services to DOE, thus helping to solve DOE EM problems.

\subsubsection{International Programs}

The change in political climate in the former Soviet Russia has opened up the potential for international cooperation between the two countries with the largest nuclear materials complexes. The MWFA will investigate technologies available in Russia that may be applicable to mixed waste streams in the United States. Technologies may also be transferred from the Unites States to Russia. Finally, the MWFA will seek other alternatives which may offer economic or technological advantages, such as using available Russian facilities for conducting technology demonstrations.

\subsubsection{Basic Research}

Basic research is stage one in a series of technology development stages. The MWFA assumes that most basic research required to support mixed waste treatment has already been conducted, or is being funded by others. Therefore, the MWFA does not provide direct financial support to basic science research. However, the focus area will work to identify those areas where a better understanding of basic science will provide the potential to significantly improve the present baseline technologies. These needs will be worked with the Environmental Management Science program to ensure research in these areas is supported. The focus area will also monitor ongoing activities within this program to identify results that may support MWFA needs. 


\section{PRODUCT SYSTEM}

The product. The MWFA funds and manages technology development projects in cooperation with the end-user organizations responsible for the actual treatment systems in which the technology will be implemented. The MWFA's specific product in these technology development projects is the Technology Performance Report (TPR).

A completed TPR will provide the end-user adequate information to enable them (either DOE or the private sector) to design, construct, and operate treatment systems that incorporate these new and/or improved technologies. Portions of each TPR provide a detailed record of the involvement of the end-user, tribal and public entities and regulators in the technology development process from its beginning, thereby assuring that the product is integrated and the technology is implementable.

The process. The MWFA product system, schematically depicted in Figure 6, begins with a thorough assessment of the end-user technology needs across the DOE Complex. The results are summarized in a published report. The needs assessment process will be reevaluated and updated each year to assure that the MWFA is addressing current customer concerns.

The end-user needs assessment serves as the basis for a detailed, systematic process of identifying and prioritizing general technological deficiencies in planned or existing mixed waste treatment systems. A published set of selection and prioritization criteria enables WTMs, with the support of other technical experts on the WTT, to construct a list of prioritized deficiencies that can be used to choose which technology development projects to fund in coming years. The prioritized list and the process by which it is built are detailed in the MWFA Integrated Technical Baseline - Phase 1. The MWFA Integrated Technical Baseline-Phase 2 documents the results of the technology funding process including cost, scope and schedule for the actual technology development projects.

A set of requirements is written for each technology development project. The Technology Development Requirement Documents (TDRDs) contain detailed performance requirements for technology, regulatory, public \& tribal and end-users.

The TDRDs serve as the basis for the Waste Type Manager and the Waste Type Team to prepare a life-cycle development plan, documented as the Development Plan (DP). Cognizant Principal Investigators then write detailed Technical Task Plans (contracts) in accordance with the requirements of the TDRD and the scope and schedule from the DP. After funding is received, the PI provides a Test Plan. By careful tracking of the TDRDs throughout the technology development process, and by managing multiple alternative solutions against the DP, integration of all aspects of the program is assured.

At the conclusion of the technology development, the PI will provide a Test Report that includes the results of the work described in the Test Plan. Other organizations will document that they have met the TDRD requirements that apply to them. This documentation and backup material will be combined into the end product - the Technology Performance Report.

The product system is outlined below. Each of the processes is described in greater detail in the MWFA Systems Engineering Management Plan, Attachment E. 

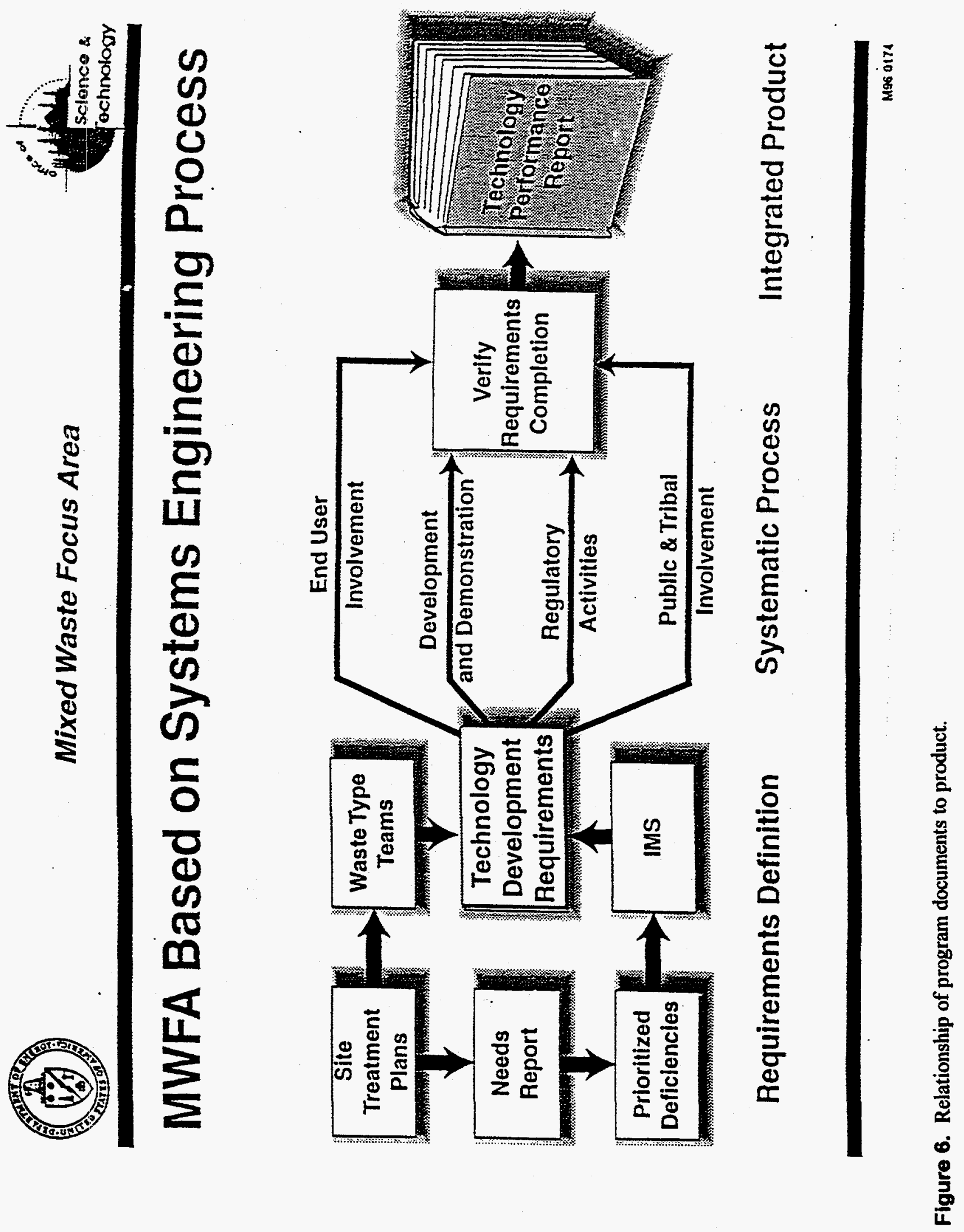


\subsection{System Definition}

The top-level system requirements are developed based on the customer's needs. The MWFA Proposal, which was based in part on DOE strategy documents, is a primary reference to the customer needs. The commitments made therein form the initial description of what the program was funded to produce. This analysis is documented in the System Requirements Document. The System Requirements Document provides the top-level system description and the identifies the requirements of the final deliverable product, i.e., implementable technologies.

\subsection{Technology Development}

The term "development" includes all activities from basic research through demonstration adequate to support detailed design. Development encompasses all activities necessary to prove that a technology is implementable; this includes not only the technical portion, but also regulatory activities, public and tribal involvement, and an end-user.

The MWFA supports development to the extent that there is an identified need and a potential enduser. The systems engineering process used is depicted in Figure 6. Needs are identified and prioritized. Requirements are developed for those needs that pass the prioritization process. Development is complete when it has been verified by formal review that these requirements have been met. Development may be terminated if it fails to retain its priority.

\subsubsection{Needs Identification and Analysis}

The identification of technologies required begins with the requirements to treat mixed waste as defined in the Site Treatment Plans. Visits, discussions and negotiations with end-users, STCGs, and contractors responsible for treating these mixed wastes, result in the identification of waste treatment technology deficiencies. Deficiencies, if resolved, could result in completing a waste treatment system not now available, or in improvements to an existing treatment system, that would allow significant cost or schedule savings.

Special studies may be conducted to determine special needs, or to reduce a set of alternative or perceived needs into a manageable list. Such needs analyses may be commissioned at any time based on new information.

All studies conducted to identify or analyze needs are issued in program documents. Examples of such needs studies and reports include the DOE Complex Needs Report, the Waste Characterization Report, the Waste Initiative Program Plan, and the Continuous Emissions Monitor Strategy.

\subsubsection{Technical Baseline}

Technology deficiencies as identified above are prioritized against predetermined criteria using a systematic, documented process. The prioritized list of deficiencies is documented in the MWFA Integrated Technical Baseline-Phase I, Attachment K. Except for "quick wins," described in Paragraph 2.5.1, and mortgaged activities (activities initiated prior to implementation of this process), only technologies related to deficiencies on the technical baseline will be supported by the MWFA, to the extent that funding is available. 


\subsubsection{Identification of Performers}

The MWFA sends copies of the Integrated Technical Baseline to prospective suppliers of technology along with a request-for-expressions-of-interest (RFI) in the Commerce Business Daily (CBD) and the Federal Register. This accomplished several objectives: notification of potential technology developers of the MWFA's needs and interests; solicitation of existing solutions where available; and identification of organizations interested in developing technical solutions.

\subsubsection{Integrated Master Schedule}

The Integrated Master Schedule (IMS), Attachment A, is a list of treatment systems identified in the site treatment plans and consent orders, with identified technology needs and associated schedules. The schisdules, the technology development activities, and the treatment system status are verified with the enduser. The IMS matches technology development efforts to the needs and schedules of the end-user, and provides a basis to determine when "sufficient" technologies have been developed.

Once a waste stream is treated and disposed of, or is targeted for a specific treatment system with no identified deficiencies, the waste stream is dropped from the IMS. When there are no waste streams with significant inventories on the IMS, "sufficient" technologies will have been developed.

\subsubsection{Technology Requirements}

For each technology deficiency identified in the MWFA Integrated Technical Baseline, (and others that have been previously funded), a set of requirements that define the product the MWFA seeks is developed and documented in a Technology Development Requirements Document.

\subsubsection{Plans}

Program work shall be conducted to written plans.

2.2.6.1 Development Plan. A specific technology may only require the involvement of one or two organizations, or it may involve many different organizations.' Integration into an end-user's or private sector participant's facility may be simple or complex. To maintain control of complex projects, a Development Plan (DP) will be necessary to allocate the technical tasks and to schedule major milestones in the multi-year technology development effort. Even for less complicated projects, a DP will be prepared to schedule major milestones, including transition stages as described in the Technology Development Transition Guidance.

The DP is prepared based on the TDRD and supporting studies and analyses such as those shown in the lower left quadrant of Figure 5. The DP describes the integrated life-cycle planning for a specific technology development and provides a mechanism for the MWFA to manage a portfolio of technology options. The DP contains descriptions of development: activities, performers, schedules, transition, success criteria, and life-cycle cost. This provides integration of the activities of multiple contributors over several funding cycles.

The MWFA Technology Development Transition Guidance, Attachment F, is a key input to the DP. The transition guidance document establishes the criteria with which to evaluate and transition the technology to the end user or commercial partner. DP then describes the implementation of the transition criteria. This guidance is patterned after the Paladino Technology Gate model. The guidance document 
establishes criteria used to support decisions to transfer funding and responsibility for development to an end-user, or a commercial partner.

2.2.6.2 Test Plans. All development and demonstration activities are conducted under an approved test plan. The test plan provides the details of the technology development and demonstration including experimental design, experimental setup, analytical methods, data to be collected, and intended precision and accuracy. Test plans shall be prepared in accordance with format and content guidance issued by the MWFA Test Plan Guidance, Attachment G.

2.2.6.3 Tribal and Public Involvement Plan. Activities conducted during the development phase that address the tribal and public involvement requirements shall be conducted according to a written plan, Attachment I. A single plan may address activities for all technology development.

\subsubsection{Regulatory Involvement Plan. The depth and length of MWFA financial support to} development and demonstration of a given technology is addressed in the MWFA Technology Development Transition Guidance, Attachment F. This guidance is patterned after the Paladino Technology Gate model. This document establishes criteria used to move a technology along its development path and negotiate the transfer of responsibility for development to an end-user, or a commercial partner.

2.2.6.5 Closure Plan. A plan will be prepared to bring the MWFA to closure. Current planning is based on providing technology development to support treatment of $90 \%$ of the mixed wastes the focus area addresses. The closure planning depends on funding levels in future years. The results will be documented in the MWFA Closure Plan, Attachment N.

\subsubsection{Reports}

The outcome of all supported activities will be documented. Key reports are identified below.

2.2.7.1 Test Reports. A detailed description of technologies developed or demonstrated shall be documented. This description shall include information in sufficient detail to demonstrate that the applicable requirements of the Technology Development Requirements Documents have been met (a given test report may only respond to a portion of the TDRD requirements).

2.2.7.2 Record of End-User Commitment. Generally it is necessary to demonstrate the existence of at least one potential end-user prior to receiving funding for a technology development effort. However, commitments to use a technology may not be made until after successful proof of the technology. It is therefore necessary to document the status of promised, potential, or actual end-users at the end of the development effort to establish that the technology is being pursued for a customer or customer need.

2.2.7.3 Tribal and Public Involvement Record. Affected tribes and members of the public shall be informed of and have input to technology development activities appropriate to their interest in and concerns about particular technologies. A record of their involvement shall be documented and maintained throughout the technology development process. This record shall include information about who was involved in the process, the content of their input to the process, and the response to their input.

2.2.7.4 Record of Regulatory Involvement. The Regulatory Group shall support development efforts either singly or as a set of technologies with commonalities. At the end of each development effort, the Regulatory staff shall document what activities they participated in that have bearing on the subject technology. 


\subsection{Quality Assurance}

Product quality is achieved by working to written plans and procedures, documenting activities, controlling governing documents, working to requirements, and verifying all products against their requirements. The requirements for a quality assurance plan are called out in Paragraph 3.5.

\subsubsection{Documentation}

Product system activities will be conducted to written plans. The outcome of activities will be documented in reports as described in the applicable activity plans. A document management and control system will be implemented as specified in Paragraph 3.4.

\subsubsection{Requirements Management and Control}

This is a requirements-driven program. Special emphasis is placed on managing product requirements. Requirements will be collected and maintained in an automated data base. This will improve completeness, traceability, and control over requirements.

\subsubsection{Data Quality Objectives}

Data quality objectives for technical development and demonstration activities will be based on requirements in the Technology Development Requirements Documents and documented in the test plans.

\subsubsection{Review}

Product documents shall be reviewed against the source requirements documents to assure that the product satisfies all applicable requirements. Formal product review teams shall be composed of knowledgeable and independent technical experts, and representatives of each of the four activity areas: end-users, tribal and public, regulatory, and technology.

\subsubsection{Trade Studies and Systems Analyses}

Trade studies and systems analyses are systematic studies to compare alternatives to decision criteria. Such criteria might include safety, protection of human health and the environment, cost schedule, reliability, maintainability and supportability. These studies are conducted to support decisions, and to assure the decision makers that they are making the best, or "quality," choice.

\subsection{The Product-Technology Performance Reports}

The MWFA product is a Technology Performance Report (TPR). The TPR is a set of documents, including as a minimum: documentation of end-user involvement; technology description reports (generally the Test Report); tribal and public involvement reports; and applicable trade studies. The complete set of documents which make up the TPR is essentially all reports prepared during the course of the technology development and demonstration activities. The major portion of the TPR will consist of the technical description which will be authored by the PI. TPRs will be provided to the customer(s) to be used as the basis for specifications for a system which will employ that technology. 


\subsection{Alternative Approaches}

Sections 2.1 through 2.4 have outlined the primary MWFA approach to defining the problem and providing a solution (the product). To increase the probability of success, the MWFA has committed to a variety of approaches to developing the most technically sound and cost effective treatment technologies possible within the constraints of limited time and money. One such alternative approach, "Quick Wins," is described below. Other opportunities may be identified and proposed for implementation. To pursue additional alternatives it must be shown how the alternative contributes to the attainment of the above described product.

\subsubsection{Quick Wins}

A small but important portion of the program budget will be directed to support development activities that lead to expedited demonstration and/or implementation of mixed waste treatment technologies. These expedited demonstration and/or implementation activities are referred to as "Quick Wins." "Expedited" means that significant impact on EM customer mixed waste problems could be realized nominally within one year.

Quick wins are similar to other development in that they must address waste streams identified in the Mixed Waste Inventory Report (traceable to a site treatment plan) and have an identified end-user.

Quick wins differ from the development sequence described in Paragraph 2.2 both in the funding and initiation. Generally quick win funding will be available within a month or two of proposal approval with a performance period limited to less than 12 months. In Paragraph 2.2, proposals must respond directly to a requirement set (TDRD) developed by the MWFA program. A quick win proposal may be directed to a deficiency, for which a Technology Development Requirements Document may not exist. This allows greater flexibility to entertain innovative concepts.

Specific types of quick wins to be considered include:

- Treatability studies on actual DOE wastes,

- Technology transfer between sites,

- Bridging the gap between technology development and implementation,

- Improved operation of existing treatment system, and,

- Resolution of regulatory issues with existing treatment system.

The results of a quick win activity will be documented in a Test Report. Results of all quick wins during a fiscal year will be compiled in a single annual Quick Win Technology Performance Report. 


\section{PROGRAM INTEGRATION AND CONTROL}

Program Integration and Control provides for the programmatic and administrative processes and support that enables the technical elements to produce the product, as defined in the previous Paragraph, and in compliance with applicable DOE Orders, national standards, and company requirements. Program Integration and Control provides primary support in the area of program execution guidance, planning budget, cost and schedule monitoring, reporting, and control. Other important functions of Program Integration and Control include information management, document control, quality assurance, and management process control.

\subsection{Program Planning and Funding}

MWFA program planning complies with applicable DOE Orders and guidance. The planning and budget process for the MWFA program are detailed in Attachment B. The primary products are Activity Data Sheets, the annual program budget, work breakdown structure (WBS), integrated program schedule, and Technical Task Plans.

\subsubsection{Budget Formulation}

The budget formulation documents a seven-year funding cycle: current year, planning year, target year, and out-years. The key budget document is an Activity Data Sheet (ADS). ADS are the key tools for prioritization and funding activities within EM; they contain work scope and budget request.

The fiscal year annual program budget is the sum of the approved funding and approved carry-over funding from the previous fiscal year. Current year (budget year) Technical Task Plans provide detailed information and breakdown for the program's budget. The planning year is the budget year plus one; for the planning year the ADS include a fixed dollar budget and prioritized scope. The target year is the budget year plus two; for the target year the ADS include target dollar budget and proposed program activities which are not prioritized. The out-years include four years beyond the target year; for the outyears the ADS include general program objectives and projected activities.

MWFA funding is initiated by the DOE Program Execution Guidance (PEG) under the Work Authorization Control System, in accordance with DOE Order 5700.7C.

Once the Financial Plan (FinPlan) reflects the funding and budget authorization, per the MWFA WBS, and approved by DOE-ID, the budget becomes the baseline to maintain and control under formal change control process and procedure.

\subsubsection{Work Breakdown Structure}

The MWFA WBS subdivides the total program into manageable units (product lines) principally by waste types.

The WBS shows the total technology development support elements to the MWFA. These elements include both the MWFA funded activities and the cross-cut programs.

The FY-1997 WBS for the MWFA is included in Attachment L. The cross-cut programs are identified by double lined boxes. 


\subsubsection{Budget and Funding Cycle}

After specific needs are identified by the MWFA, formal, directed calls-for-proposal are issued by DOE-ID MWFA Program Management to DOE Operations Offices and separate requests-for-proposal are issued, depending on whether private industry, university, or DOE labs are determined to be more capable of performing the technology development activity. Responses are received by the MWFA, reviewed, ranked, and prioritized for funding determination. The MWFA notifies the respective DOE Operations Offices, university, or private industry of the selection results. The DOE then issues the PEG authorizing the selected technology performer to proceed with planning the work scope. For work proposed to be conducted in a DOE laboratory, a Technical Task Plan (TTP) is generated in accordance with the format established by the DOE, see Attachment J. The TTP defines the cost, scope, and schedule of work proposed. The project starts when the TTP is approved and funding is provided. Private sector and university work are funded through approved DOE procurement documentation.

\subsection{Performance Criteria}

Performance criteria are established against which progress is reported. Criteria are established for technical, cost, and schedule performance.

\subsubsection{Technical Performance Criteria}

The Government Performance and Results Act of 1993 requires EM to submit an annual performance plan to Office of Management and Budget (OMB) and to report performance against that plan. Performance measures established by the MWFA must roll up to the summary level performance measurements for EM-50.

EM-50 has established three summary performance measures applicable to the MWFA in FY-96. The EM-50 FY 1996 Annual Performance Plan, Attachment M, allocates these summary level performance measures to each separately funded technology. The MWFA shall work to those individual criteria. The MWFA shall report monthly on progress towards meeting those criteria, and provide an annual recommendation for changes to those criteria.

\subsubsection{Cost Performance Criteria}

The criteria for satisfactory cost performance for both the overall program and individual projects (funded TTPs), is $\pm 10 \%$ (with a threshold of $\$ 50$ thousand) of budgeted cost of work performed (BCWP).

\subsubsection{Schedule Performance Criteria}

The criteria for satisfactory schedule performance for both the overall program and individual projects (funded TTPs), is $\pm 10 \% 150 \mathrm{~K}$ of budgeted cost of work scheduled (BCWS).

\subsubsection{Performance Reporting}

Monthly and annual reports are used to monitor and manage program activities. Routine management reports are prepared, by either the Managing and Operating or prime contractor at each Operations Office, to assess the current status of the program or project, identify trends, and forecast future 
progress. Technical, cost, and schedule performance are compared with the above criteria, and correction plans are formulated for all significant (as based on the criteria) problems.

The DOE Progress Tracking System (PTS) is the vehicle used for monthly reporting purposes within DOE-EM. LMTTCO management support provides each TPO with monthly reporting data at the TTP level by the 10th working day of the month. This data is reviewed, approved, and submitted to DOE by the 15 th working day of the month.

The PTS requires reporting on the following topics, as a minimum:

- Scope

- Significant problems, issues, and concems

- Corrective actions

- Summary and technical assessment

- Cost and schedule status

- Cost and schedule variance analysis beyond thresholds

- Major accomplishments.

\subsection{Change Control}

Change control processes are applicable to the cost, schedule and scope baselines formulated from ITPs approved for the current fiscal year.

Control of these baselines and the methods for authorizing and recording baseline changes are accomplished to the intent of DOE ORDER 4700.1 "Project Management System."

Changes to baselines may be originated by EM- $30,-40,-50$, and -60 customers or by participants within the technology development programs themselves. Changes to documents that detail the baseline (ADS, backup documentation, and TTPs) are regulated through the formal change control process described in Attachment C. Other changes that do not affect the baseline are administered through management controls instituted at the TPO level.

\subsection{Information Management}

The principal products of the MWFA are technical and programmatic information. This information is generated, collected, accounted for, and disseminated within organizations internal and external to the MWFA. Communications and proper management of information is critically important to the mission of the focus area as a national program. The information management system must be responsive to national and international needs including, universities, industry, public and tribal governments, DOE, and other government agencies. 


\subsubsection{Internet Information Availability}

MWFA contractors and participants are distributed throughout the United States. The World Wide Web and File Transfer Protocol (FTP) server on the Internet are tools that aid the program in disseminating information to the geographically distributed participants involved in the MWFA. Internet communication includes a home page, http://wastenot.inel.gov/mwfa, with a document search capability centered on a Microsoft Access database. This system, which has been operational since early 1996, provides access to a wide spectrum of documents in electronic form.

\subsubsection{Document Configuration Control}

The MWFA maintains a Document Configuration Control function that includes review, approval, distribution, and change control. Document Configuration Control meets the requirements of DOE Order 1324.5A, "Records Management Program," 4330.4B, "Maintenance Management Program," 5480.19, "Conduct of Operations," and 5700.6C, "Quality Assurance." The responsibility to identify the documents that need to comply with this Paragraph, and the responsibility to ensure the documents meet the requirements, belongs to the Technical Program Officer, at each site, or a duly delegated subordinate. For the national program, LMTCO management support will issue a procedure which defines our document configuration control and identifies the documents which will be controlled. This procedure will be issued in the first quarter of 1997.

\subsubsection{Communications}

Under this paragraph, the term "communications," refers to letters, memos, telephone phone conversations, telefaxes, electronic mail (e-mail), and other such vehicles which are not addressed under Paragraph 3.4.2. LMTTCO management support will issue a procedure which can be used to identify communications that must be treated as program documents or records. This procedure shall also identify the approvals, distributions, storage, and retention, if any, required for the various communications.

\subsubsection{Project Files}

Each PI is responsible to establish, maintain, and close project files (those files generated in the course of carrying out a development and demonstration activity funded under a MWFA TTP.) Sufficient documentation shall be generated to provide adequate scientific and technical documentation of the project activities and results. For the national program, LMTCO management support will issue a procedure which defines our document configuration control and identifies the documents which will be controlled. This procedure will be issued in the first quarter of 1997 . These records shall be stored and managed in accordance with requirements in Paragraph 3.4.2.

\subsection{Quality Assurance, Environmental Health and Safety, and Security}

All contractors and subcontractors shall have a records management and document control system, a Quality Assurance Program, an Environmental Plan, a Safety and Health Plan, and a Security Plan. In addition, all work performed by a DOE Laboratory, with funding provided by the MWFA, shall comply with applicable DOE Orders and, in particular, those referenced in this Paragraph. These program support functions and/or plans can be addressed by identifying an existing function or plan. Alternately, a MWFA-specific function or plan can be developed or written that satisfies the requirements of the applicable DOE Orders. Because the DOE generally allows a graded approach to these functions and/or 
plans they may be addressed as part of other management documents such as the Statement of Work, interface agreements, management plan, etc., depending upon the scope of the activity funded. It is the responsibility of each site Technical Program Officer, through whom MWFA funding is received, to ensure these plans have been addressed. It is the responsibility of the DOE-ID MWFA Program Manager to ensure that these functions and/or plans have been addressed for the national MWFA program. These requirements shall be incorporated by reference in subcontracts, as applicable.

\subsubsection{Quality Assurance}

3.5.1.1 Quality Assurance Program. MWFA program shall work to a Quality Assurance Program (QAP). DOE-ID will comply with the Department of Energy Idaho Operations Quality Management Plan, issued December 1995. All contractors or support organizations will follow a Quality Assurance Plan that meets the requirements of DOE Order 5700.6C. If a MWFA contractor or support organization operates within a facility with an established QAP that meets the intent of the above requirements, then a reference to that QAP in the project management documents is sufficient.

3.5.1.2 Audit Functions. Audit functions as addressed in DOE Order 4330.4B "Maintenance Management Program" and 5700.6C, "Quality Assurance" shall be identified. This will include support to audits conducted by personnel other than the project personnel.

3.5.1.3 Management Accountability. All individuals involved in the Program are responsible for cornpliance to the Quality Assurance Program and for the quality of their work. DOE-ID will comply with the Department of Energy Idaho Operations Quality Management Plan, issued December 1995. All contractors or support organizations will follow a Quality Assurance Plan that meets the requirements of DOE Order 5700.6C.

\subsubsection{Safety and Health Plan}

The MWFA will comply with the applicable sections of DOE 0231.1 "Safety and Health Reporting Requirements", 0 440.1 "Worker Protection Management for DOE Federal and Contractor Employees," 0450.2 "Identifying, Implementing, and Complying with Environmental Safety and Health Regulations," 5480.1B "Environmental, Safety, and Health Programs for Department of Energy Operations", and 5483.1B "Occupational Safety and Health Program. Each TTP shall address ES\&H considerations and requirements specific to that set of activities.

\subsubsection{Environmental Plan}

The MWFA will comply with the applicable sections of DOE Order 5400.1 "General Environmental Protection Program", 0 451.1/5440.1E "National Environmental Policy Act Compliance Program," and O 5480.1B "Environmental, Safety, and Health Programs for Department of Energy Operations. The support site personnel will determine which environmental requirements apply and will identify the actions required for compliance. This determination and action plan will be included in management documentation of each TTP-funded project.

\subsubsection{Security Plan}

The MWFA will comply with applicable sections of DOE $0470.1 / 5630.11 B$ "Safeguards and Security Program." The cognizant Technical Program Officer will determine which safeguards and security requirements apply and will identify the actions required for compliance. 


\subsection{Conflict of Interest}

MWFA personnel may be asked to evaluate technologies and make recommendations to DOE on information provided from contractor host site, contractor affiliates, or other affiliate companies (such as site contract teaming members, or commercial competitors of the contractor. To mitigate the potential for organizational conflicts of interests within this highly interactive organizational environment, an Organizational Conflicts of Interest (OCI) Plan shall be prepared and implemented.

The policy of the MWFA is to adhere to the highest standards of business ethics, to maintain a work force that is dedicated to the highest standards of personal ethics and to diligently identify and avoid or mitigate the effects of OCI. MWFA requires personnel supporting the MWFA to comply with this policy.

The $O C I$ mitigation plan, Attachment $O$, shall be written to specifically address the special circumstances of the MWFA work. Contractors supporting the MWFA may have additional contractorspecific OCI policies and procedures. The MWFA OCI plan is suppiemental to those contractor-specific policies and procedures, but in the event of conflicting requirements shall, for MWFA personnel, take precedence over those contractor-specific polices and procedures. 


\section{RESPONSIBILITY ASSIGNMENT MATRICES}

This section contains two tables which identify the principal responsibilities of the organizations described in Section 1.3

\subsection{Deliverable Responsibility}

In this paragraph, the term "MWFA product" is expanded from the definition used in Section 2 to included all deliverables. A tacit assumption is then made that all MWFA products can be represented by a document. A list of major program documents is shown in Table 1. In the case of classes of documents, such as "Test Plans," the generic test plan is listed.

For each document on the list, Column 2 identifies the organization responsible for preparation of the document, and Column 3 identifies the organization responsible for approving the document. The documents have been ordered principally by their role in the product system, beginning with the requirements documents and ending with the product documents.

\subsection{Functional Responsibility}

The second approach to establishing responsibility is to identify functions that organizations or organizational positions are responsible for performing. This has been done in the matrix, Table 2. These functions encompass the functions identified in the organizational descriptions in Section 1.3, but are generally more specific. Section 1.3 and Table 2 are consistent, but not equivalent. Likewise, although for each deliverable in Table 1, there could be the associated functions - provide input, prepare, review, and approve - some but not all of these functions are replicated in Table 2.

Table 1. MWFA document responsibility and assignment matrix.

Document

Author Organization

Approval Organization

MWFA Proposal

Program Management Plan

Systems Engineering Management Plan

System Requirements Document

Waste Type Team Manual

Organizational Conflict of Interest Plan

Te:hnology Development Transition Guidance
DOE-ID and LMTCO

DOE EM-50

LMITCO Program Integration and Control

LMTTCO Systems Engineering

LMITCO Systems Engineering

LMITCO Systems Engineering

LMITCO Program Integration and Control

LMITCO Systems Engineering
LMITCO Program Manager

LMITCO Program Manager

LMITCO Program Manager

DOE-ID

LMTCO OCI

LMITCO Program Manager 
Table 1. (continued).

\begin{tabular}{|c|c|c|}
\hline Document & Author Organization & Approval Organization \\
\hline $\begin{array}{l}\text { Technical Task Plan Development } \\
\text { Guidance }\end{array}$ & $\begin{array}{l}\text { LMITCO Program Integration and } \\
\text { Control }\end{array}$ & LMITCO Program Manager \\
\hline $\begin{array}{l}\text { Tribal and Public Involvement } \\
\text { Record Guidance }\end{array}$ & $\begin{array}{l}\text { LMTTCO Public and Tribal Nations } \\
\text { Group }\end{array}$ & LMITCO Program Manager \\
\hline Test Plan Guidance Document & Technical Resource Team & LMITCO Deputy Manager \\
\hline DOE Complex Needs Report & $\begin{array}{l}\text { Waste Type Manager/Waste Type } \\
\text { Team }\end{array}$ & LMITCO Deputy Manager \\
\hline $\begin{array}{l}\text { MWFA Integrated Technical } \\
\text { Baseline }\end{array}$ & LMITCO Systems Engineering & LMITCO Program Manager \\
\hline Integrated Master Schedule & LMITCO System Engineering & LMITCO Program Manager \\
\hline $\begin{array}{l}\text { Technology Development } \\
\text { Requirements Document }\end{array}$ & $\begin{array}{l}\text { Waste Type Manager/Waste Type } \\
\text { Team }\end{array}$ & $\begin{array}{l}\text { LMITCO Deputy Manager/ } \\
\text { Waste Type Manager }\end{array}$ \\
\hline Development Plan & Waste Type Team & Waste Type Manager \\
\hline Privatization Plan & $\begin{array}{l}\text { LMTTCO Industry and University } \\
\text { Group }\end{array}$ & DOE-ID \\
\hline $\begin{array}{l}\text { Tribal and Public Involvement } \\
\text { Plan }\end{array}$ & $\begin{array}{l}\text { LMTCO Public and Tribal Nations } \\
\text { Group }\end{array}$ & LMITCO Program Manager \\
\hline Closure Plan & LMITCO Systems Engineering & DOE-ID \\
\hline Regulatory Development Plan & LMITCO Regulatory Group & LMITCO Program Manager \\
\hline Technical Task Plan & Principal Investigator & $\begin{array}{l}\text { DOE-ID and Technical } \\
\text { Program Officer }\end{array}$ \\
\hline Technical Data Acquisition Plan & Principal Investigator & $\begin{array}{l}\text { DOE-D and Technical } \\
\text { Program Officer }\end{array}$ \\
\hline Test Plan & Principal Investigator & Waste Type Manager \\
\hline Integrated Program Schedule & $\begin{array}{l}\text { LMTTCO Program Integration and } \\
\text { Control }\end{array}$ & LMTTCO Deputy Manager \\
\hline MWFA Technical Monthly & Principal Investigator & $\begin{array}{l}\text { LMTTCO Program Integration } \\
\text { and Control }\end{array}$ \\
\hline Progress Tracking System Report & Principal Investigator & Technical Program Officer \\
\hline MWFA Monthly Business Review & $\begin{array}{l}\text { DOE-ID and LMTCO Program } \\
\text { Integration and Control }\end{array}$ & DOE \\
\hline Activity Data Sheets & $\begin{array}{l}\text { LMITCO Program Integration and } \\
\text { Control }\end{array}$ & DOE \\
\hline Risk Data Sheets & $\begin{array}{l}\text { LMITCO Program Integration and } \\
\text { Control }\end{array}$ & DOE and DOE-ID \\
\hline Trade Study & LMITCO Systems Engineering & LMITCO Deputy Manager \\
\hline Test Report & Principal Investigator & Waste Type Manager \\
\hline $\begin{array}{l}\text { Tribal and Public Involvement } \\
\text { Record }\end{array}$ & $\begin{array}{l}\text { LMTTCO Public and Tribal Nations } \\
\text { Group }\end{array}$ & $\begin{array}{l}\text { LMTTCO Deputy Manager/ } \\
\text { Waste Type Manager }\end{array}$ \\
\hline
\end{tabular}


Table 1. (continued).

Document

Regulatory Development Report

Review Report (Formal Product

Reviews)

Technology Performance Report

Document Performance Summary

Report
Author Organization

LMITCO Regulatory Group

LMITCO Systems Engineering

Waste Type Manager/Waste Type

Team

Colorado Center for Environmental Management
Approval Organization

LMITCO Deputy Manager

LMTTCO Deputy Manager

DOE-ID

DOE 
THIS PAGE INTENTIONALLY BLANK 
Table 2. Functional Responsibilities Matrix.

\begin{tabular}{|c|c|c|c|c|c|c|}
\hline \multirow[b]{3}{*}{ Organization } & \multicolumn{6}{|c|}{ Functional Activities } \\
\hline & \multicolumn{6}{|c|}{ Technology Development } \\
\hline & $\begin{array}{c}\text { Program } \\
\text { Management } \\
\end{array}$ & Requirements & Plans & Test & Analysis & Product \\
\hline EM-50 & $\begin{array}{l}\text { Sets MWFA } \\
\text { Program Policy and } \\
\text { Direction, has } \\
\text { authority for overall } \\
\text { management of the } \\
\text { MWFA Program }\end{array}$ & & & & & \\
\hline EM- $30,-40,-60$ & & Identify needs & & & & Use technology \\
\hline $\begin{array}{l}\text { National Technical } \\
\text { Work Group (NTW) }\end{array}$ & & & & & & $\begin{array}{l}\text { Support } \\
\text { development of } \\
\text { national permit } \\
\text { procedures for } \\
\text { MW treatment }\end{array}$ \\
\hline $\begin{array}{l}\text { Interstate } \\
\text { Technology } \\
\text { Reguilatory } \\
\text { Cooplerative Work } \\
\text { Group (ITRC) }\end{array}$ & & & & $\begin{array}{l}\text { Provides } \\
\text { multi-state } \\
\text { participation } \\
\text { in acceptance } \\
\text { of } \\
\text { demonstration } \\
\text { testing } \\
\text { protocols } \\
\end{array}$ & & \\
\hline $\begin{array}{l}\text { DOE Environmental } \\
\text { Research and } \\
\text { Technology } \\
\text { Development } \\
\text { Steering Committee }\end{array}$ & $\begin{array}{l}\text { Establishes overall } \\
\text { priorities and policy, } \\
\text { provides } \\
\text { programmatic } \\
\text { direction }\end{array}$ & & & & & \\
\hline $\begin{array}{l}\text { Office of Science and } \\
\text { Technology Board of } \\
\text { Direstors }\end{array}$ & $\begin{array}{l}\text { Provides top-level } \\
\text { program oversight }\end{array}$ & $\begin{array}{l}\text { Ensures technology } \\
\text { development program } \\
\text { is responsive to EM } \\
\text { priorities }\end{array}$ & $\begin{array}{l}\text { Establishes } \\
\text { overall priorities } \\
\text { and policy for the } \\
\text { MWFA }\end{array}$ & & & \\
\hline $\begin{array}{l}\text { DOE' Management } \\
\text { Teana }\end{array}$ & & & $\begin{array}{l}\text { Advises on work } \\
\text { across the MWFA }\end{array}$ & & & $\begin{array}{l}\text { Monitor } \\
\text { implementation of } \\
\text { technologies }\end{array}$ \\
\hline $\begin{array}{l}\text { Technical Program } \\
\text { Officer }\end{array}$ & $\begin{array}{l}\text { Responsible for day- } \\
\text { to-day management, } \\
\text { direction, and cost } \\
\text { control of } \\
\text { technology } \\
\text { development at their } \\
\text { site }\end{array}$ & & $\begin{array}{l}\text { Supports planning } \\
\text { of the MWFA } \\
\text { relative to } \\
\text { individual } \\
\text { operations offices }\end{array}$ & & & \\
\hline DOE-ID & $\begin{array}{l}\text { Authority for overall } \\
\text { management of the } \\
\text { MWFA program, } \\
\text { lead organization } \\
\text { with management } \\
\text { responsibility for the } \\
\text { MWFA }\end{array}$ & $\begin{array}{l}\text { Review/approve } \\
\text { program technology } \\
\text { development activities }\end{array}$ & $\begin{array}{l}\text { Provides the } \\
\text { technology } \\
\text { development } \\
\text { strategy to } \\
\text { tectnology } \\
\text { developers }\end{array}$ & & & $\begin{array}{l}\text { Approve the final } \\
\text { product }\end{array}$ \\
\hline $\begin{array}{l}\text { LMITCO Program } \\
\text { Management }\end{array}$ & $\begin{array}{l}\text { Provides day-to-day } \\
\text { national-level } \\
\text { program } \\
\text { management of the } \\
\text { MWFA }\end{array}$ & $\begin{array}{l}\text { Define requirements } \\
\text { for deficiencies, } \\
\text { recommend Integrated } \\
\text { Tectmology } \\
\text { Development Frogram } \\
\text { to DOE-DD }\end{array}$ & Approve plans & & & Review/concur \\
\hline $\begin{array}{l}\text { Waste Type } \\
\text { Managers }\end{array}$ & & $\begin{array}{l}\text { Prioritize deficiencies } \\
\text { and select } \\
\text { technologies, review } \\
\text { TTPs for technology } \\
\text { development }\end{array}$ & & & $\begin{array}{l}\text { Review } \\
\text { technology } \\
\text { development }\end{array}$ & \\
\hline
\end{tabular}




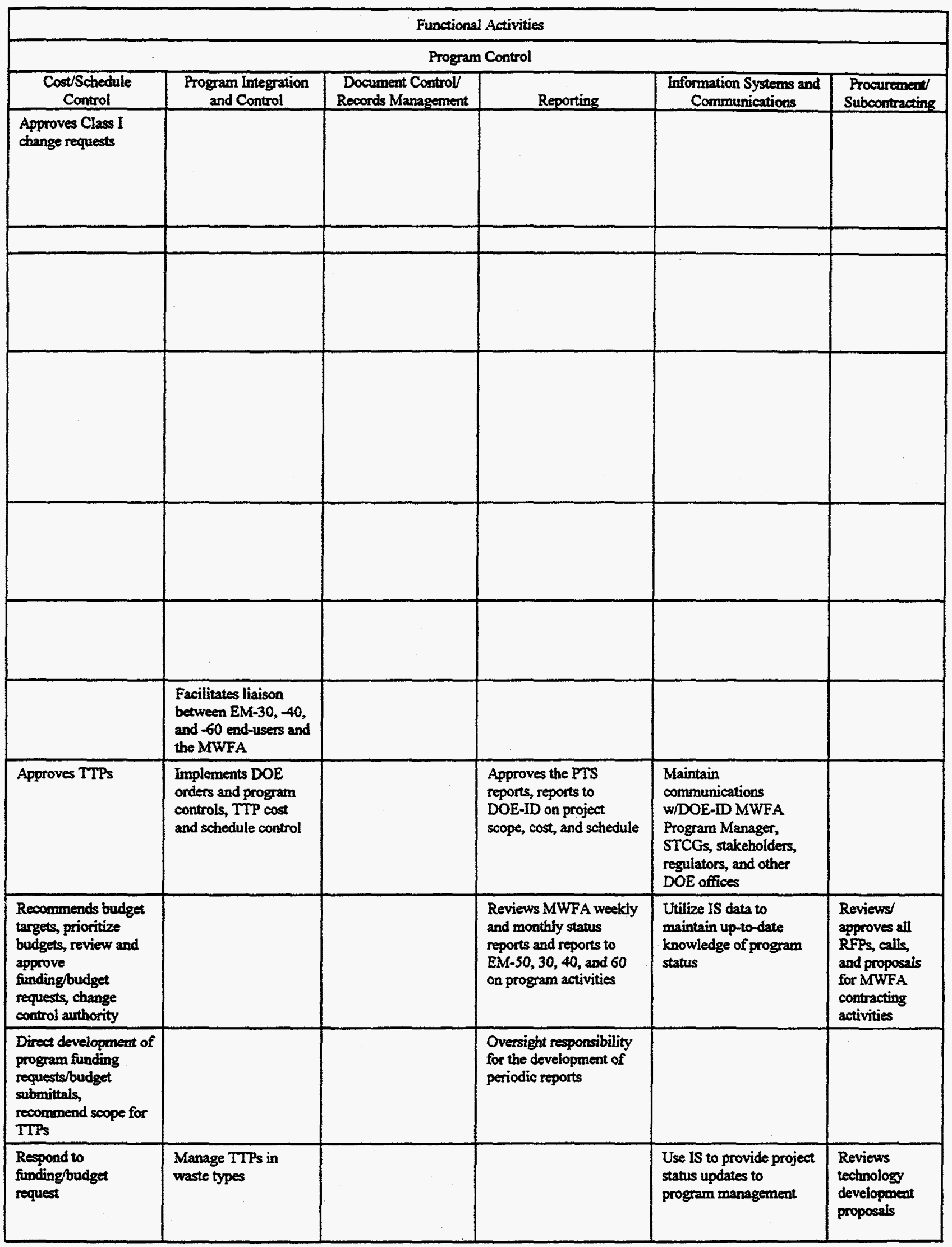


Table 2. (continued).

\begin{tabular}{|c|c|c|c|c|c|c|}
\hline \multirow[b]{3}{*}{ Organization } & \multicolumn{6}{|c|}{ Functional Activities } \\
\hline & \multicolumn{6}{|c|}{ Technology Development } \\
\hline & $\begin{array}{c}\text { Program } \\
\text { Management }\end{array}$ & Requirements & Plans & Test & Analysis & Product \\
\hline $\begin{array}{l}\text { LMrTCO Program } \\
\text { Integration and } \\
\text { Control }\end{array}$ & & $\begin{array}{l}\text { Responsible for } \\
\text { developing and } \\
\text { maintaining the } \\
\text { Integrated Program } \\
\text { Schedule (IPS) }\end{array}$ & & & & \\
\hline Systums Engineering & $\begin{array}{l}\text { Track technical } \\
\text { interfaces on the } \\
\text { program }\end{array}$ & $\begin{array}{l}\text { Define system } \\
\text { architecture, track and } \\
\text { manage technical } \\
\text { requirements }\end{array}$ & Input to plans & & $\begin{array}{l}\text { Conduct } \\
\text { reviews, } \\
\text { identify, } \\
\text { organize } \\
\text { and/or } \\
\text { conduct trade } \\
\text { studies }\end{array}$ & \\
\hline $\begin{array}{l}\text { Regulatory and } \\
\text { University Team }\end{array}$ & & $\begin{array}{l}\text { Identify regulatory } \\
\text { requirements for } \\
\text { technology } \\
\text { development activities }\end{array}$ & $\begin{array}{l}\text { Prepares } \\
\text { regulatory } \\
\text { development plan }\end{array}$ & & & $\begin{array}{l}\text { Prepare } \\
\text { regulatory } \\
\text { report }\end{array}$ \\
\hline $\begin{array}{l}\text { Public and Tribal } \\
\text { Nations Team }\end{array}$ & & $\begin{array}{l}\text { Identify publicitribal } \\
\text { stakeholders } \\
\text { requirements }\end{array}$ & $\begin{array}{l}\text { Prepares Tribal and } \\
\text { Public Involvement } \\
\text { Plan }\end{array}$ & & & $\begin{array}{l}\text { Prepare record } \\
\text { of public and } \\
\text { tribal nations } \\
\text { involvement }\end{array}$ \\
\hline $\begin{array}{l}\text { Tectinical Resource } \\
\text { Tearn }\end{array}$ & & $\begin{array}{l}\text { Support WTMs in } \\
\text { prioritizing } \\
\text { deficiencies and } \\
\text { selecting technologies } \\
\text { for development }\end{array}$ & & & $\begin{array}{l}\text { Evaluates } \\
\text { development } \\
\text { activities, } \\
\text { participates } \\
\text { in formal } \\
\text { reviews }\end{array}$ & \\
\hline $\begin{array}{l}\text { Technical Support } \\
\text { Teann }\end{array}$ & & $\begin{array}{l}\text { Define requirements } \\
\text { for deficiencies }\end{array}$ & & & & \\
\hline \multicolumn{7}{|l|}{ Waste Type Team } \\
\hline $\begin{array}{l}\text { Site Technology } \\
\text { Coordination Groups } \\
\text { (STCGs) }\end{array}$ & & $\begin{array}{l}\text { Provide sites' needs to } \\
\text { MWFA }\end{array}$ & $\begin{array}{l}\text { Guide life-cycle } \\
\text { planning for } \\
\text { technology transfer } \\
\text { at sites }\end{array}$ & & & $\begin{array}{l}\text { Guide life-cycle } \\
\text { planning for } \\
\text { technology } \\
\text { transfer at sites }\end{array}$ \\
\hline \multicolumn{7}{|l|}{$\begin{array}{l}\text { Site Operations } \\
\text { Contact }\end{array}$} \\
\hline Waste Type Teams & & Identify deficiencies & Input to plans & & $\begin{array}{l}\text { Evaluate } \\
\text { results }\end{array}$ & \\
\hline $\begin{array}{l}\text { Principal } \\
\text { Investigator }\end{array}$ & & & Prepares test plans & $\begin{array}{l}\text { Responsible } \\
\text { for technical } \\
\text { progress and } \\
\text { direction of } \\
\text { tasks being } \\
\text { conducted, } \\
\text { perform } \\
\text { technology } \\
\text { development } \\
\text { and demon- } \\
\text { stration } \\
\text { activities }\end{array}$ & $\begin{array}{l}\text { Develops } \\
\text { detailed test } \\
\text { plan, } \\
\text { performs } \\
\text { analysis, and } \\
\text { writes a test } \\
\text { report } \\
\text { detailing } \\
\text { results of the } \\
\text { work } \\
\text { described in } \\
\text { the test plan }\end{array}$ & $\begin{array}{l}\text { Documents } \\
\text { results as a part } \\
\text { of tectmical } \\
\text { performance } \\
\text { report }\end{array}$ \\
\hline
\end{tabular}




\begin{tabular}{|c|c|c|c|c|c|}
\hline \multicolumn{6}{|c|}{ Functional Activities } \\
\hline \multicolumn{6}{|c|}{ Program Control } \\
\hline $\begin{array}{l}\text { Cost/Schedule } \\
\text { Contral }\end{array}$ & $\begin{array}{l}\text { Program Integration } \\
\text { and Control } \\
\end{array}$ & $\begin{array}{c}\text { Document Control } \\
\text { Records Management }\end{array}$ & Reporting & $\begin{array}{c}\text { Information Systems and } \\
\text { Communications } \\
\end{array}$ & $\begin{array}{c}\text { Procurement } \\
\text { Subcontracting }\end{array}$ \\
\hline $\begin{array}{l}\text { Develops project } \\
\text { budgets-reviews cost } \\
\text { estimates }\end{array}$ & $\begin{array}{l}\text { Manage integration } \\
\text { and control function }\end{array}$ & $\begin{array}{l}\text { Provide for MWFA } \\
\text { documents }\end{array}$ & $\begin{array}{l}\text { Responsible for } \\
\text { developing all reporting } \\
\text { activities for the MWFA, } \\
\text { provide roll-up PTS } \\
\text { information to WTMs, } \\
\text { LMTTCO management, } \\
\text { and DOE-ID }\end{array}$ & $\begin{array}{l}\text { Develop and maintain } \\
\text { MWFA complex-wide IS }\end{array}$ & \\
\hline $\begin{array}{l}\text { Responsible for } \\
\text { developing and } \\
\text { maintaining the } \\
\text { integrated master } \\
\text { schedule }\end{array}$ & $\begin{array}{l}\text { Prepare SEMP system } \\
\text { requirements } \\
\text { document }\end{array}$ & & $\begin{array}{l}\text { Provides direction and } \\
\text { tracks the Complex } \\
\text { Needs Report and other } \\
\text { program related } \\
\text { documentation }\end{array}$ & & . \\
\hline \multicolumn{6}{|l|}{$\begin{array}{l}\text { Prepares budgets for } \\
\text { regulatory/university } \\
\text { activities-reviews } \\
\text { external budgets }\end{array}$} \\
\hline \multicolumn{6}{|l|}{$\begin{array}{l}\text { Prepare budgets for } \\
\text { public and tribal } \\
\text { nations activities }\end{array}$} \\
\hline & & & $\begin{array}{l}\text { Provides reports and } \\
\text { updates on program } \\
\text { technology development } \\
\text { activities }\end{array}$ & & \\
\hline \multirow[t]{4}{*}{$\begin{array}{l}\text { Coordinate } \\
\text { budget/funding } \\
\text { request activities for } \\
\text { individual projects }\end{array}$} & & & $\begin{array}{l}\text { Provides weekly status } \\
\text { reports and } \\
\text { prepares/develops year- } \\
\text { end report on program } \\
\text { status }\end{array}$ & $\begin{array}{l}\text { Utilize IS to keep } \\
\text { complex-wide } \\
\text { organization briefed on } \\
\text { program status }\end{array}$ & \\
\hline & $\begin{array}{l}\text { Interface with } \\
\text { program and site } \\
\text { operations contact }\end{array}$ & & & & \\
\hline & & & & $\begin{array}{l}\text { Enhance } \\
\text { communications between } \\
\text { sites, MWFA, and local } \\
\text { regulators on technology } \\
\text { development activities }\end{array}$ & \\
\hline & $\begin{array}{l}\text { Interface with PIs and } \\
\text { programs }\end{array}$ & & $\begin{array}{l}\text { Point of contact for } \\
\text { requesting sites' } \\
\text { technical } \\
\text { information/status of } \\
\text { MWFA interests }\end{array}$ & & \\
\hline $\begin{array}{l}\text { Initiates } \\
\text { funding budget } \\
\text { request for individual } \\
\text { projects, responsible } \\
\text { for scheduling all } \\
\text { activities related to } \\
\text { individual projects }\end{array}$ & $\begin{array}{l}\text { Manage individual } \\
\text { technology } \\
\text { development projects }\end{array}$ & & $\begin{array}{l}\text { Responsibie for PTS } \\
\text { inputs/updates-tracking } \\
\text { TTPs, provide monthly } \\
\text { reports on individual } \\
\text { projects under their } \\
\text { purview }\end{array}$ & & $\begin{array}{l}\text { Develops } \\
\text { proposals for } \\
\text { techmology } \\
\text { development } \\
\text { activities }\end{array}$ \\
\hline
\end{tabular}




\section{REFERENCES}

DOE-ID Contract DE-AC07-94ID13223

Federal Facility Compliance Act

DOE 0231.1

DOE 0430.1

DOE 0440.1

DOE 0450.2

DOE 0 451.1/5440.1E

DOE Order 1324.5A

DOE Order 4330.4B

DOIE Order 4700.1

DOE Order 5400.1

DOE Order 5440.1E

DOE Order 5480.1B

DOE Order 5480.19

DOE Order 5481.1B

DOE Order 5483.1B

DOE 0 5630.11B

DOE Order 5700.6C

DOE Order 5700.7C

DOE/LLW-217
- Safety and Health Reporting Requirements

- Life-cycle Asset

- Worker Protection Management for DOE

Federal and Contractor Employees

- Identifying, Implementing, and Complying with Environmental Safety and Health Regulations

- National Environmental Policy Act Compliance Program Management

- Records Management Program

- Maintenance Management Program

- Project Management System

- General Environmental Protection Program

- National Environmental Policy Act Compliance Program

- Environmental, Safety, and Health for the Department of Energy Operations

- $\quad$ Conduct of Operations .

- Safety Analysis and Review

- Occupational Safety and Health Program

- Safeguards and Security Program

- Quality Assurance

- Work Authorization System

- DOE Waste Treatability Guidance

Double Numbered Orders, such as, "DOE 0 451.1/5440.1E," mean that both Orders are still effective, and both have the same name. The effective one is a function of the Managing and Operating contractor's contract with the DOE. 


\section{ATTACHMENTS}

The following table identifies each document considered to be an attachment to this PMP. The status of each document is provided effective October 1, 1996. Current status of any document or copies of the issued documents may be obtained by contacting MWFA Document Control, 208-526-1861.

Attachment $\mathrm{L}$ is included with this report.

Table 3. Identification and Status of PMP Attachments

\begin{tabular}{|c|c|c|c|}
\hline Attachment & Document Title & Author & Status \\
\hline A & Integrated Master Schedule & Don Norman & Issued \\
\hline B & Planning \& Budget Cycle for MWFA Program & Rudy Theriault & Current \\
\hline $\mathrm{C}$ & MWFA Programs Baseline Change Management Process & Lewis Rounds & Working Draft \\
\hline D & Waste Type Team Manual (INEL 95/0522) & George Beitel & Issued \\
\hline E & System Engineering Management Plan & George Beitel & Rough Draft \\
\hline $\mathbf{F}$ & Technology Development Transition Guidance & Jim Herzog & Rough Draft \\
\hline G & Test Plan Guidance & Dirk Gomert & Final Draft \\
\hline $\mathrm{H}$ & Privatization Plan & Mike Connolly & Rough Draft \\
\hline 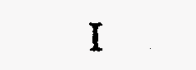 & Tribal and Public Involvement Plan & Roger Scott & Rough Draft \\
\hline$J$ & Technical Task Plan Guidance & DOE & Issued \\
\hline $\mathbf{K}$ & MWFA Integrated Technical Baseline (DOE/ID-10524) & Mike Connolly & Issued \\
\hline $\mathrm{L}$ & Work Breakdown Structure & Ken Merrill & Issued \\
\hline $\mathbf{M}$ & EM-50 FY 1996 Annual Performance Plan & DOE & Issued \\
\hline $\mathrm{N}$ & Closure Plan & Don Norman & To Be Done \\
\hline 0 & $\begin{array}{l}\text { Mitigation Plan for Potential Organizational Conflicts of } \\
\text { Interest in the Mixed Waste Focus Area (MWFA), } \\
\text { September } 19,1995\end{array}$ & Jim Okeson & Issued \\
\hline
\end{tabular}




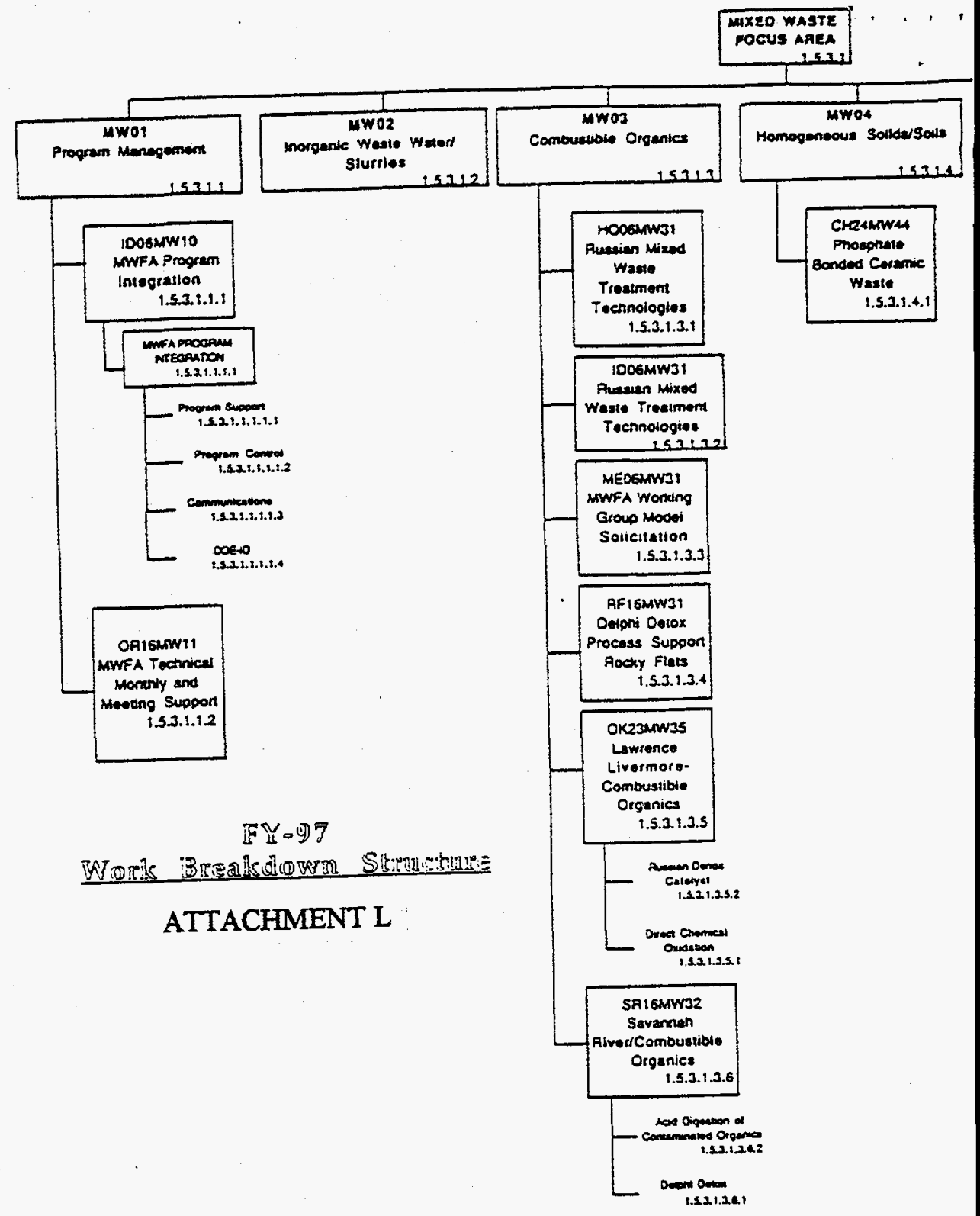




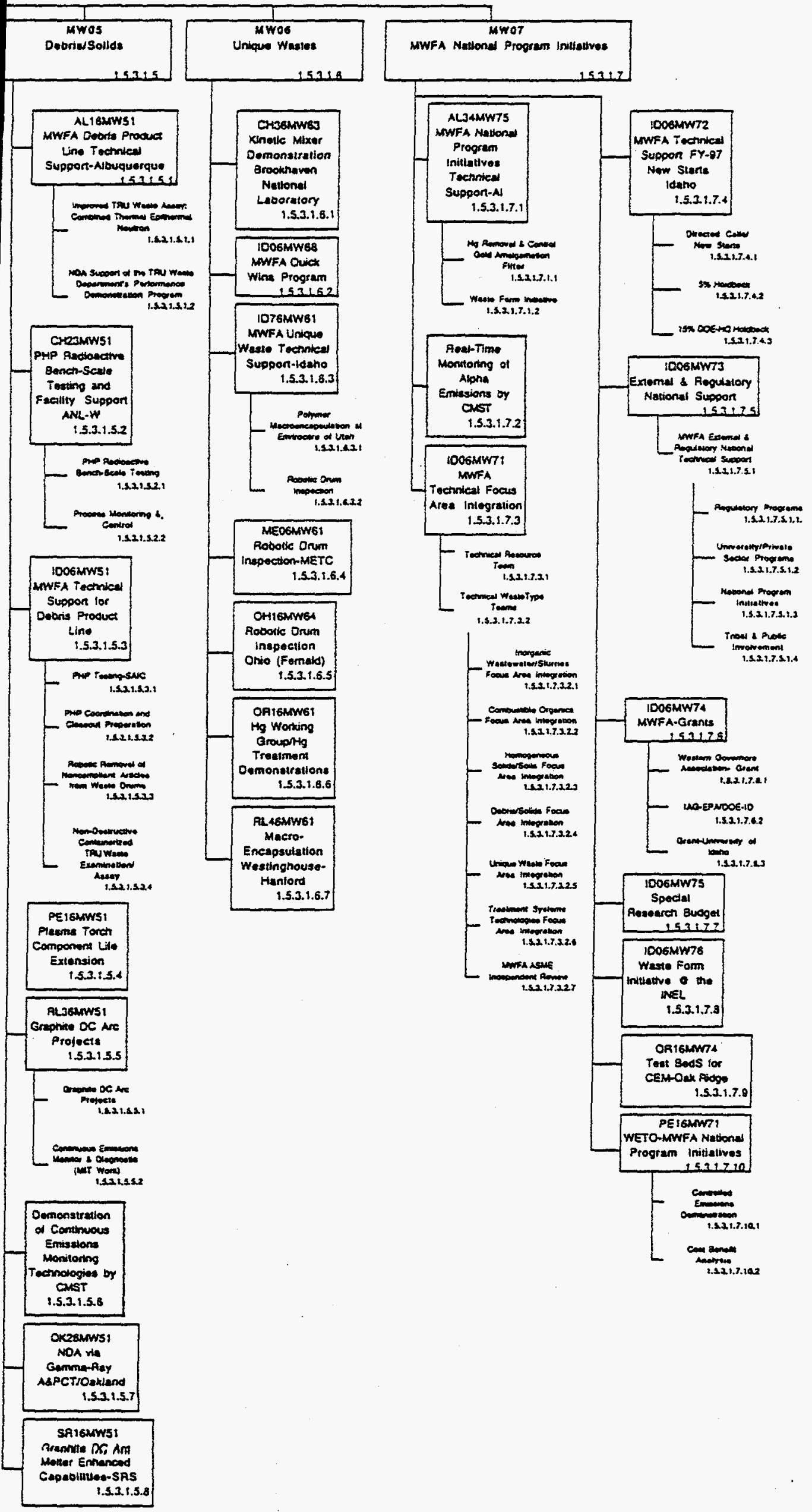

